\title{
Hazai képződményekból szeparált kvarcok jellemzői az OSL kormeghatározás szempontjából
}

\author{
ThamónÉ Bozsó Edit ${ }^{1}$, Füri Judit ${ }^{1}$, Kovács István János² ${ }^{2}$ BIró Tamás ${ }^{3}$, KirÁly Edit ${ }^{1}$, Nagy Attila ${ }^{4}$, \\ TÖrÖKnÉ Sinka Mariann ${ }^{5}$, KónYa Péter ${ }^{1}$, MÉSzÁRosné Turi Judit ${ }^{1}$, Vígh Csaba ${ }^{1}$ \\ 'Magyar Bányászati és Földtani Szolgálat, 1143 Budapest, Stefánia út 14. (bozso.edit@mbfsz.gov.hu) \\ ${ }^{2}$ MTA Csillagászati és Földtudományi Kutatóközpont, Sopron, Csatkai Endre u. 6-8. \\ ${ }^{3}$ Eötvös Loránd Tudományegyetem, Földrajzi és Földtani Intézet, Budapest, Pázmány Péter sétány 1/c. \\ ${ }^{4}$ Anteusz Bt., 1086 Budapest, Harminckettesek tere 6. \\ ${ }^{5}$ Pénzügyminisztérium, 1139 Budapest, Váci út 81-83.
}

\section{Characteristics of quartz separates of different formations in Hungary from the aspect of OSL dating}

Abstract

The Optically Stimulated Luminescence (OSL) dating started in 2004 in the Geological Institute of Hungary, then continued in the successor Geological and Geophysical Institute of Hungary, and the Mining and Geological Survey of Hungary. Our OSL ages have contributed to the reconstructions of palaeohydrography and palaeomorphology as well as the timing of neotectonic movements and archaeological sites among others.

Principally, quartz is used for dating because it is an abundant and resistant mineral of the sediments and it serves as a natural retrospective dosimeter that is trapping and storing charges in the point defects of its crystal lattice.

During the dating of Upper Pleistocene and Holocene sediments, it has been recognised that the luminescence properties of quartz and its suitability for OSL dating show local differences. For example, in some places of Hungary, quartz has much dimmer luminescence than in other areas of the country, or it is saturated due to lower radioactive radiation, which makes OSL dating challenging. The aim of this study was to find the causes of these local differences. Quartz was separated from some plutonic, volcanic, metamorphic and older sedimentary rocks and sediments of Hungary, which can be source of some Upper Pleistocene and Holocene sediments in Hungary. Beside OSL measurements, for the detection of the chemical impurities that can cause defects in the crystal lattice, Laser Ablation Inductively Coupled Plasma Mass Spectrometry (LA-ICP-MS), Micro-Fourier Transform Infrared Spectrometry (Micro-FTIR) and Infrared Spectrometry were applied. Thermal Analysis and X-Ray Diffraction were applied for the characterisation of the quartz separates. The concentration of the radioactive elements in the studied formations was also determined based on laboratory High-Resolution Gamma-Ray Spectrometry.

The results of the OSL measurements indicated that sediments, sedimentary rocks and some volcanic tuffs give brighter or more intensive luminescence than the quartz of the studied metamorphic and plutonic rocks. The quartz grains of only a few formations are appropriate for OSL dating if they get into the Pleistocene or Holocene sediments. They are solely sediments and sedimentary rocks, certain Upper Miocene, Upper Miocene - Pliocene and Upper Oligocene sands of Kálla Gravel, Zagyva and Törökbálint Sandstone formations.

The results of the LA-ICP-MS measurements indicated $\mathrm{Li}, \mathrm{Na}, \mathrm{Al}, \mathrm{P}, \mathrm{K}, \mathrm{Ti}$ and $\mathrm{Ba}$ impurities in the quartz grains, while Micro-FTIR analysis detected coupled substitution of $\mathrm{Al}^{3+}+\mathrm{H}^{+}$at the position of $\mathrm{Si}^{4+}$ incorporated as $\mathrm{AlOH}$ structural hydroxyl, and molecular water as well. These impurities partly are present in mineral phases, as clay minerals or smectite, and mica, according to the results of XRD, Thermal Analysis and Infrared Spectrometry.

The causes of the local differences in luminescence properties of quartz grains and their suitability for OSL dating are probably their different source rocks, and diverse thermal and sedimentary history. The quartz grains that are originated directly from metamorphic and plutonic rocks by erosion show unfavourable OSL properties, probably because, during their long cooling period, they relax most of the point defects in their crystal lattice that were formed during their formation on high temperature. The OSL properties of the quartz grains of the sediments and sedimentary rocks are more favourable due to the repeated cycles of radioactive irradiation and the zeroing of the OSL in sunshine which increase the sensitivity of quartz.

Keywords: OSL, Micro-FTIR, LA-ICP-MS, XRD, thermal analysis, gamma spectrometry

Összefoglalás

Az OSL (Optically Stimulated Luminescence) kormeghatározás alkalmazása a Magyar Állami Földtani Intézetben 2004-ben kezdődött, majd a jogutód Magyar Földtani és Geofizikai Intézetben folytatódott, és a Magyar Bányászati és Földtani Szolgálatban jelenleg is folyik. A felső-pleisztocén és holocén üledékek OSL kormeghatározása során tett megfigyeléseink szerint a kvarcok lumineszcens tulajdonságai és OSL kormeghatározásra való alkalmassága helyi 
eltéréseket mutat. Ezeknek az eltéréseknek az okait kerestük. Vizsgáltuk a kvarc eltérő forráskőzeteinek hatását olyan kvarcgazdag magmás, metamorf és idősebb üledékes képződményekből nyert kvarcszeparátumokon, amelyek hazánkban jelenleg a felszínen is előfordulnak, és anyaguk a negyedidőszaki üledékbe is bekerülhetett. Az OSL mérések mellett a kvarcszemcsék kristályrácshibáit okozó szennyeződések kimutatására LA-ICP-MS, mikro-FTIR és IR spektrometriai méréseket alkalmaztunk. A kvarcszeparátumok pontosabb jellemzéséhez fénymikroszkópos vizsgálatot, valamint termoanalitikai és röntgen-pordiffrakciós elemzéseket végeztünk. A kvarcokat befoglaló képződmények radioaktívelemtartalmát gamma-spektrometriai mérések segítségével határoztuk meg.

OSL mérési eredményeink alapján az üledékes képződmények és egyes vulkáni tufák kvarcszeparátumai fényesebb, nagyobb intenzitású lumineszcenciát adtak, mint a vizsgált metamorf és mélységi magmás kôzetek. Közvetlenül, az első mállási és szállítási ciklus után az üledékekbe kerülve csupán néhány üledékes képződmény kvarcszemcséi lennének alkalmasak a kormeghatározásra.

A kvarcok OSL tulajdonságait meghatározó kristályrács hibáit az LA-ICP-MS vizsgálat szerint Li, Na, Al, P, K, Ti és $\mathrm{Ba}$ beépülése okozhatja, és a mikro-FTIR mérésekkel kimutatott, a $\mathrm{Si}^{4+}$ iont helyettesítő $\mathrm{Al}^{3+}+\mathrm{H}^{+}$, azaz $\mathrm{AlOH}$ szerkezeti hidroxil, valamint molekuláris víz. A nagyobb intenzitású OSL-t adó kvarcszeparátumok befoglaló képződményei kisebb K- és Th-tartalommal rendelkeznek, mint a gyengébb OSL-t kibocsátóké.

A negyedidôszaki üledékek kvarcainak lumineszcens tulajdonságaiban és OSL kormeghatározásra való alkalmasságában mutatkozó helyi eltérések oka az eltérő forráskőzeteik, valamint különböző hő- és üledékes történetük lehet. A mélységi magmás és metamorf kőzetek elsődleges lepusztulásából származó kvarcok kedvezőtlen OSL tulajdonságát az eredményezheti, hogy bár magas hőmérsékleten képződve sok kristályrácshiba alakult ki bennük, de azok nagy részét lassú kihúlésük során elvesztették. Az üledékes képződmények kvarcszemcséinek kedvezőbb OSL tulajdonságai elsôsorban a szállításuk és áthalmozódásuk során az ismétlődő radioaktív besugárzási, azaz OSL felépülési, és napfényen az OSL lenullázódási ciklusoknak köszönhetô, melyek növelik a kvarc lumineszcens érzékenységét.

Tárgyszavak: OSL, Mikro-FTIR, LA-ICP-MS, RTG, termoanalitika, gamma-spektrometria

\section{Bevezetés}

A Magyar Állami Földtani Intézetben, majd annak jogutódjaiban, a Magyar Földtani és Geofizikai Intézetben és a Magyar Bányászati és Földtani Szolgálatban 2004 óta folyik OSL kormeghatározás (OSL: Optically Stimulated Luminescence, optikailag gerjesztett lumineszcencia), miután NÁDOR Annamária kezdeményezésére beszerzésre került egy dán gyártmányú Risø TL/OSL mérőberendezés. Az üledékek kvarcszemcséin végzett OSL mérések segítségével általában maximum 60-100 ezer éves késô-pleisztocén és holocén betemetôdési korok határozhatók meg. Az elmúlt 15 év során az OSL kormeghatározási eredményeink hozzájárultak többek között ôsvízrajzi (NÁDOR et al. 2007, THAMÓ-Bozsó et al. 2007a, b, CSERKÉSZ-NAGY et al. 2012, VAYSSIÈRE et al. 2019) és domborzatfejlôdési rekonstrukciókhoz (ThAmó-Bozsó et al. 2010a, FáBIÁN et al. 2014), neotektonikai események datálásához (SiNGH et al. 2008, THAмó-Bozsó et al. 2010b), valamint régészeti lelőhelyek korának meghatározásához (T. BIRó et al. 2010, FIEBIG et al. 2009, MARQUET et al. 2016, 2019).

A kvarc gyakori ásvány, és radioaktív sugárzás hatására szabad töltéseket képes csapdázni, majd hosszú idő́n keresztül tárolni, és így a környezeti radioaktív sugárzás hatását megőrizni mint természetes retrospektív doziméter. Ezek a tulajdonságai alkalmassá teszik a lumineszcens kormeghatározásra, sốt az ember által okozott radioaktív szennyezések mértékének kimutatására is. A csapdákat a kristályrács hibapontjai alkotják. A betemetett üledékek kvarcszemcséiben a környezeti radioaktív sugárzás energiája által gerjesztett elektronok a csapdákba kerülnek, a helyükön visszamaradt pozitív töltésú lyukak pedig az ún. rekombinációs centrumokban csapdázódnak (AITKEN 1998, BøTTER-JENSEN et al. 2003, GötZE et al. 2005). A kvarcban a vegyértéksáv és a vezetési sáv közötti viszonylag széles tiltott sáv elősegíti az elektroncsapdák és rekombinációs centrumok kialakulását (BøTTER-JENSEN et al. 2003). Bizonyos csapdákból az elektronok fénnyel vagy hővel történő gerjesztés, azaz megvilágítás vagy melegítés hatására kiszöknek, és újraegyesülnek, rekombinálódnak a lyukakkal, amit gyenge és rövid, általában néhány másodperces fénykibocsátásban megnyilvánuló energiafelszabadulás, azaz OSL kísér. A csapdák teljes kiürülése a kormeghatározás során az OSL óra lenullázódását jelenti. A kibocsátott lumineszcens fény spektruma jellemzô a rekombinációs centrumokra, míg a fény intenzitása arányos a csapdázott töltések számával, illetve az ásványt ért radioaktív sugárzás dózisával a telítődési szintig. A kvarc lumineszcenciájára az ultraibolya (UV), a kék és a vörös hullámhossztartomány a legjellemző́bb. Mivel az üledékek kvarcai főként UV lumineszcenciát bocsátanak ki, ezért az OSL kormeghatározásban legelterjedtebben alkalmazott Risø TL/OSL mérômúszerek a közeli UV 340 480 nm-es mérési tartományban detektálják a kvarc lumineszcenciáját.

A kvarc dozimetriai tulajdonságait a kristályrács hibái határozzák meg. $\mathrm{A} \mathrm{SiO}_{2}$ mellett nyomokban mindig tartalmaz idegen ionokat ( $\mathrm{pl} . \mathrm{Al}^{3+}, \mathrm{Ti}^{4+}, \mathrm{B}^{3+}, \mathrm{Ge}^{4+}, \mathrm{Fe}^{3+}, \mathrm{H}^{+}, \mathrm{OH}^{-}$) és intersticiális hiányokat (pl. O-hiány), illetve többleteket, melyek ponthibákat képeznek a kristályrácsban (BøTTERJensen et al. 2003, Preusser et al. 2009).

A lumineszcens kormeghatározás során tett megfigyeléseink szerint a kvarcok lumineszcens tulajdonságai és kormeghatározásra való alkalmassága helyi eltéréseket mutat. Magyarországon (pl. THAмó-Bozsó et al. 2007b, 2010a,b; CSERKÉSZ-NAGY et al. 2012) és a Kárpát-medencén belül Magyarországhoz közeli területeken (Érmellék, Románia: ThAmó-Bozsó et al. 2007a; Donau-Auen Nemzeti Park, Ausztria: FieBig et al. 2009) a késó-pleisztocén-holocén korú folyóvízi és eolikus üledékek kvarcszemcséinek lumi- 
neszcenciája változó, sok helyen viszonylag gyenge. Hazai folyóink üledékeiből vizsgált kvarcok lumineszcens tulajdonságai is jelentôs eltéréseket mutatnak BRATYIK et al. (2019) mérései szerint. Ugyanakkor az általunk Franciaországból vizsgált minták zöme erős, fényes lumineszcenciát adott (pl. MARQUET et al. 2016, 2019; VAYSSIÈRE et al. 2019). Viszont az Indiából (SINGH et al. 2008) és Iránból (THAMóBozsó et al. 2019) származó minták kvarcainak lumineszcenciája legtöbbször nagyon gyenge, halvány volt, és nem is bizonyultak alkalmasnak a kormeghatározásra. A kvarcok egyre növekvő radioaktív sugárzás hatására fellépő lumineszcenciájának változása is helyi eltéréseket mutat.

Ezeknek a különbségeknek az okait kerestük. Ezért vizsgáltuk a kvarc eltérô forráskőzeteinek hatását. 20172018 során a hazai pleisztocén és holocén üledékek forráskőzeteiként számításba vehetô egyes hazai magmás, metamorf és idôsebb üledékes képződményekből nyert kvarcszeparátumokon OSL méréseket végeztünk. Mivel a lumineszcencia végsố soron az ásványok kristályrácshibáira vezethető vissza, amit főként különböző ionok és molekulák beépülése okoz, ezért ezeket LA-ICP-MS, mikro-FTIR és IR spektrometria segítségével tanulmányoztuk. A kvarcszeparátumok pontosabb jellemzéséhez termoanalitikai és röntgenelemzéseket is alkalmaztunk. A radioaktív sugárzás hatásának vizsgálata céljából a kvarcokat befoglaló képződmények U, Th és K tartalmát gamma-spektrometriai mérésekkel határoztuk meg.

A kvarcok OSL kormeghatározási tartományába eső felsô-pleisztocén és holocén üledékek Magyarországon elsôsorban folyóvízi vagy eolikus eredetűek, és kiterjedt lehordási területról származnak. Fő́ folyóink közül a Duna fő́ként az Alpokból, a Nyugati-Kárpátokból, a Cseh-maszszívumból és a Dunántúli-középhegységből szállít törmelékanyagot elsősorban különböző metamorfitokból, herciniai és idősebb granitoidokból, neogén vulkanitokból, mezozoos karbonátokból, flis és molasz képződményekből. A Tisza és mellékfolyói nagyrészt a Kárpátok, az Erdélyi-középhegység és az Északi-középhegység területérôl érkeznek. Üledékanyaguk forráskőzeteit főként neogén andezitek, riolitok, bazaltok és azok tufái, perm savanyú vulkanitok, jura bazaltok, különböző korú metamorfitok, granitoidok, neogén és idôsebb pleisztocén molasz üledékek, kréta-paleogén flis, perm és mezozoos törmelékes üledékes kőzetek és alárendelten karbonátok alkotják (további részletek THAmó-Bozsó \& Ó. Kovács, 2007). Kisebb vízfolyásaink helyi képződmények anyagát szállítják. A késố-pleisztocén-holocén korú eolikus üledékek nagyrészt a folyóvízi üledékek áthalmozódásával keletkeztek.

\section{Minták, mintaelókészítés, vizsgálati módszerek}

A mintáink kiválasztása során nem a késô-pleisztocén és holocén korú üledékek legfőbb forráskőzeteire koncentráltunk, hanem arra törekedtünk, hogy néhány hazai, a felszínen előforduló metamorf, mélységi magmás, vulkáni és üledékes képződmény kerüljön vizsgálatra. A kvarcok optikai lumineszcens tulajdonságait, és az azt befolyásoló tényezôket huszonhárom mintán tanulmányoztuk. A minták nagy részét a Magyar Bányászati és Földtani Szolgálat kőzetgyújteményéből kaptuk, egy mintát a Herman Ottó Múzeum Földtörténeti és Természetrajzi Tára bocsátott a rendelkezésünkre, tizenegy minta 2017-2018 során került begyújtésre. A minták lelőhelyét az 1. ábra mutatja, főbb jellemzőiket (anyag, rétegtani besorolás, kor) és a lelőhelyükre, illetve a leírásukra vonatkozó fő́bb hivatkozásokat az I. táblázat tartalmazza. A minták nagy része üledékes képződmény, három metamorfit, két mélységi magmás kőzet és négy vulkanit van közöttuik. A minták közel fele neogén korú, a fennmaradókból hét paleogén, hat paleozoos.

A magmás, metamorf és üledékes kôzetminták elókészítése során elôször törést alkalmaztunk pofástörő, majd golyósmalom segítségével. Ezekből és az üledékmintákból a vizsgálatokra a 0,1-0,3 mm-es, illetve a 0,10-0,16 mm-es frakciót szitálással különítettük el, melyekből a karbonátok kioldása $10 \%$-os $\mathrm{HCl}$, az esetlegesen előforduló szerves anyagok eltávolítása 20\%-os $\mathrm{H}_{2} \mathrm{O}_{2}$ segítségével történt. Majd 40\%-os HF-os étetés következett, melynek időtartama a nagyobb kvarctartalmú minták (homok, kvarcit) esetében rövidebb, 60 perc, a többi minta esetében hosszabb, 90 perc volt. Az étetés célja az OSL kormeghatározás során a kvarcszemcsék alfasugárzással érintett külsô, 10-15 $\mu \mathrm{m}$-es felszíni rétegének a lemaratása, valamint a szennyezó ásványok, elsôsorban a kvarc OSL mérési tartományában lumineszcenciát adó földpátok elbontása volt. Az étetés után az esetleg visszamaradt fluoridok kioldásához 10\%-os HCl-t

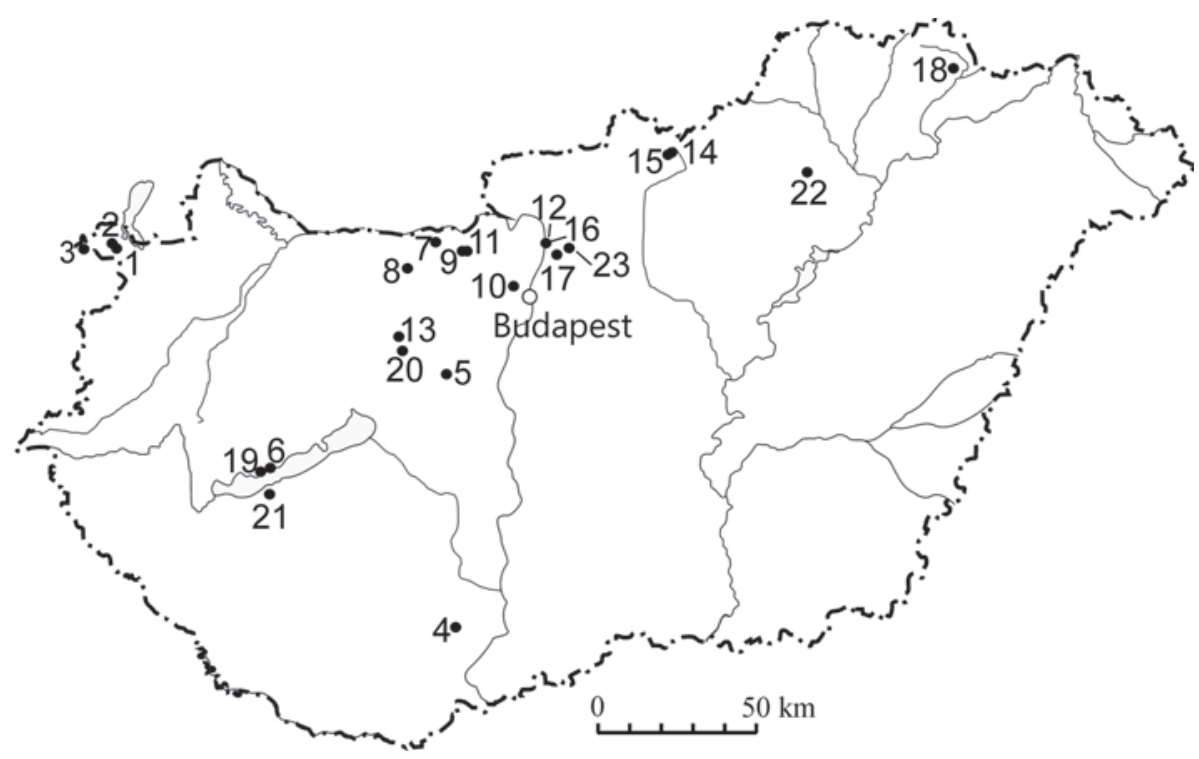

1. ábra: A minták lelőhelye (Mintakódok jelentése az I. táblázatban)

Figure 1. Location of the samples (Meaning of the code numbers is in Table I.) 
I. táblázat. A vizsgált minták lelőhelye és főbb jellemzői (F: Formáció, T: Tagozat)

Table I. Location and main characteristics of the studied samples (F: Formation, T: Member)

\begin{tabular}{|c|c|c|c|c|c|}
\hline $\begin{array}{l}\text { Minta } \\
\text { Sample }\end{array}$ & $\begin{array}{l}\text { Lelöhely } \\
\text { Location }\end{array}$ & $\begin{array}{l}\text { Képzödmény } \\
\text { Formation }\end{array}$ & $\begin{array}{c}\text { Rétegtani egység } \\
\text { Lithostratigraphic unit }\end{array}$ & $\begin{array}{l}\text { Kor } \\
\text { Age }\end{array}$ & $\begin{array}{l}\text { Hivatkozás } \\
\text { Reference }\end{array}$ \\
\hline 1 & Sopron, Nándormagaslat & leukofillit & $\begin{array}{l}\text { Tolvajárki Leukofillit T. } \\
\text { (Füzesárki Fehérpala F.) }\end{array}$ & paleozoikum & Kisházi \& Ivancsics 1989 \\
\hline 2 & Sopron, Bögre-forrás & gneisz & Sopronbánfalvi Gneisz F. & paleozoikum & $\begin{array}{l}\text { Kisházi \& Ivancsics } 1989 \\
\text { Török } 1998\end{array}$ \\
\hline 3 & Brennbergbánya, Kovácsárok & csillámpala & Vöröshídi Csillámpala F. & paleozoikum & Fülöp 1990 \\
\hline 4 & Mórágy községi kőfejtő & gránit & Mórágyi Gránit F. & kora-karbon & Jantsky 1979 \\
\hline 5 & Sukoró, kőbánya & gránit & Velencei Gránit F. & késö-karbon & Nagy 1967 \\
\hline 6 & Balatonrendes & homokkö & Balatonfelvidéki Homokkő F. & középsö-késö-perm & Majoros 1999 \\
\hline 7 & $\begin{array}{l}\text { Lábatlan, cementgyár } \\
\text { homokbánya }\end{array}$ & homok & Bajnai T. (Dorogi F.) & középső-eocén & Kercsmár 2018 \\
\hline 8 & Tatabánya, Keselö-hegy & homok & Tokodi F. idősebb része & középső-eocén (bartoni) & Kercsmár 2018 \\
\hline 9 & Tokodaltáró, délkelet & homok & Tokodi $\mathrm{F}$. fiatalabb része & középsô-eocén (bartoni) & Gidai 1972 \\
\hline 10 & Budapest, Nagyhárshegy & homokkő & Hárshegyi Homokkõ F. & kora-oligocén & $\begin{array}{l}\text { Kaszanitzky } 1956 \\
\text { Korpás } 1981\end{array}$ \\
\hline 11 & Tokodaltáró, homokbánya & homok & Törökbálinti Homokkő F. & késő-oligocén & Korpás 1981 \\
\hline 12 & Göd, Duna-part & homokkő & Törökbálinti Homokkő F. & késő-oligocén & $\begin{array}{l}\text { Jámbor et al. } 1966 \\
\text { Oláh et al. } 2014\end{array}$ \\
\hline 13 & Mór, délkelet & homok & Csatkai F. & késő-oligocén & Korpás 1981 \\
\hline 14 & Kazár, Tordas-tetō & riolittufa & Gyulakeszi Riolittufa F. & kora-miocén (ottnangi) & Hámor 1985 \\
\hline 15 & Kazár, kelet & homokkő & $\begin{array}{l}\text { Kazári Homokkő T. } \\
\text { (Egyházasgergei F.) }\end{array}$ & kora-miocén (kárpáti) & Hámor 1985 \\
\hline 16 & Göd, Duna-part & $\begin{array}{l}\text { bontott } \\
\text { dácittufa }\end{array}$ & Tari Dácittufa F. & kora-miocén (kárpáti) & Jámbor et al. 1966 \\
\hline 17 & Fót, északnyugat & $\begin{array}{l}\text { bontott } \\
\text { dácittufa }\end{array}$ & Tari Dácittufa F. & kora-miocén (kárpáti) & Jámbor et al. 1966 \\
\hline 18 & Sárospatak, Botkő-bánya & $\begin{array}{l}\text { hidrokvarcit } \\
\text { (riolitból) }\end{array}$ & Tokaji Vulkanit F. & $\begin{array}{l}\text { középső-késő-miocén } \\
\text { (késő-szarmata- } \\
\text { pannóniai) }\end{array}$ & $\begin{array}{l}\text { Gyarmati } 1974 \\
\text { Hahn et al. } 1998\end{array}$ \\
\hline 19 & Kisörs, homokbánya & homok & Kállai Kavics F. & késö-miocén (pannóniai) & $\begin{array}{l}\text { Krizsán P. } 1963 \\
\text { Bence et al. } 1999\end{array}$ \\
\hline 20 & Fehérvárcsurgó, homokbánya & üveghomok & Kállai Kavics F. & késö-miocén (pannóniai) & \begin{tabular}{|l|} 
Vecsernyés 1966 \\
Bence et al. 1999 \\
\end{tabular} \\
\hline 21 & Fonyód, magaspart & homok & $\begin{array}{l}\text { Tihanyi T. } \\
\text { (Újfalui Homokkő F.) }\end{array}$ & késő-miocén (pannóniai) & Sztanó et al. 2013 \\
\hline 22 & Bükkábrány, lignitbánya & homok & $\begin{array}{l}\text { Bükkaljai Lignit T. } \\
\text { (Újfalui Homokkő F.) }\end{array}$ & $\begin{array}{l}\text { késö-miocén-pliocén } \\
\text { (pannóniai) }\end{array}$ & \begin{tabular}{|l} 
Jaskó 1981 \\
Hahn et al. 1998 \\
\end{tabular} \\
\hline 23 & Veresegyház, délkelet & homok & Zagyvai $\mathrm{F}$. & $\begin{array}{l}\text { késö-miocén-pliocén } \\
\text { (pannóniai) }\end{array}$ & Jámbor et al. 1966 \\
\hline
\end{tabular}

használtunk, és a keletkezett finomabb frakció eltávolításához 0,1 mm-es lyukátmérőjú szitán való átmosást alkalmaztunk. Ezután a kvarcdús részleg elkülönítése desztillált vizes átöblítést és szárítást követôen nehézfolyadék $\left(2,67 \mathrm{~g} / \mathrm{cm}^{3}\right.$ sûrúségú nátrium-polivolframát, azaz $\mathrm{SPT}$ : $\left.\mathrm{Na}_{6}\left[\mathrm{H}_{2} \mathrm{~W}_{12} \mathrm{O}_{40}\right] \mathrm{H}_{2} \mathrm{O}\right)$ segítségével történt. Végül a kvarc- szemcséket $10 \mathrm{~mm}$ átmérőjú rozsdamentes acél mintatartó korongok (diszkek) közepére rögzítettük $5 \mathrm{~mm}$ átmérôjú területre szilikon olaj (spray) segítségével, úgy, hogy a szemcsék egyetlen réteget alkossanak. A minták előkészítése a törést és ôrlést leszámítva a lumineszcens kormeghatározásra begyuujiött üledékek elókészítésével azonos lépé- 
sekből állt, de nem sötétben, illetve gyenge vörös fény mellett történt, mint a kormeghatározás során, hanem normál laborvilágítás mellett, mivel ezeken a képződményeken nem akartunk OSL kormeghatározást végezni, hiszen ahhoz túlságosan idősek.

A 0,10-0,16 mm-es kvarcszemcsékből álló szeparátumok OSL vizsgálatát az MBFSZ Risø TL/OSL DA-20 múszerével a SAR (Single Aliquot Regenerative Dose) OSL protokoll (WinTLE \& MURRAY 2006) szerinti mérésekkel végeztük. Ennek során a lumineszcenciát kék fényú $(470 \pm 20 \mathrm{~nm})$ LED-ekkel történő megvilágítás gerjesztette, a lumineszcens fényt a közeli UV-tartományban $(340 \pm 80$ nm) Hoya U-340 szúroó közbeiktatásával PM-cső detektálta. Egyes tesztmérésekhez infravörös fényt $(870 \pm 40 \mathrm{~nm})$ használtunk. A múszerben a kvarc radioaktív besugárzását bétasugárzást kibocsátó $\mathrm{Sr}-90$ zárt sugárforrás végezte, melynek dózisteljesítménye a mérések idején $0,08 \mathrm{~Gy} / \mathrm{s}$ volt. A kvarc OSL tulajdonságainak vizsgálata során hasonló méréseket alkalmaztunk, mint az OSL kormeghatározás folyamán. Ezeknek a méréseknek a részleteit egy korábbi publikációnkban ismertettük (THAMÓNÉ Bozsó \& NAGY 2011). A kiértékelésnél az Analyst v.4.31.9 szoftvert is használtuk.

Vizsgáltuk többek között a kvarcszeparátumok OSL mérési görbéit (szignáljait) és növekedési görbéit. Az összehasonlíthatóság érdekében az OSL szignálok egy része lenullázás, azaz $280^{\circ} \mathrm{C}$-on történt megvilágítás, majd 16,6 Gy radioaktív besugárzás és $240{ }^{\circ} \mathrm{C}$-os előmelegítés után került mérésre. Az OSL növekedési görbék az egyre növekvő radioaktív sugárzások hatására fellépő lumineszcenciát mutatják. Általában az OSL növekedése eleinte gyorsabb ütemú, lineáris, majd lassabb, exponenciális. A növekedési görbék elóállítása során a kvarcszeparátumok „természetes” dózisának mérésére is sor került. Elvégeztük az OSL szignálok komponensekre bontását. Azt, hogy egy kvarcszeparátum OSL mérésével pontosan meghatározható-e az ismert dózisú radioaktív laboratóriumi besugárzás nagysága, dózisvisszamérési teszttel vizsgáltuk. A kvarcok OSL mérése során fellépő érzékenységváltozást három kvarcszeparátumon vizsgáltuk a kormeghatározásnál szokásos SAROSL protokollt negyvenszer ismételt ciklusban alkalmazva. A ciklusok során kék fényú megvilágítást, 26 Gy dózisú radioaktív besugárzást, az OSL mérések elôtt $260{ }^{\circ} \mathrm{C}$-os előmelegítést és 13 Gy tesztdózist alkalmaztunk. A minták úgy kerültek kiválasztásra, hogy kis, közepes és nagy intenzitású OSL-lel rendelkezô kvarcszeparátumok is legyenek köztük. A kvarcfrakciók tisztaságát az OSL kormeghatározás során is alkalmazott infravörös-teszttel ellenőriztük. Ehhez a lumineszcenciát elóbb infravörös, majd kék fényú megvilágítás után mértük. Egy kvarcszeparátum akkor tekinthetô tisztának az OSL szempontjából, ha az IR-fényre adott lumineszcenciája nem éri el a kék fényre adott lumineszcencia 10\%-át. Ezt a tesztet minden egyes részminta mérésekor a méréssorozat legvégén elvégeztük.

A kvarcszeparátumokat polarizációs mikroszkóppal is tanulmányoztuk a szemcsék kanadabalzsamba (duktil) ágyazásával készült preparátumokon. A kristályrácshibákat okozó szennyeződések kimutatására a kvarcszemcséken LA-
ICP-MS (lézerablációs induktív csatolású plazma tömegspektrométeres), valamit mikro-FTIR (Fourier Transform Infrared) és IR spektrometriai méréseket alkalmaztunk.

Az LA-ICP-MS vizsgálat kétkomponensú múgyantába (Araldit D) ágyazott, majd szilicium-karbiddal (SiC) megcsiszolt és gyémánttal polírozott kvarcszemcséken készült. A mérések az MBFSZ Perkin Elmer Elan DRCII típusú ICP-MS múszeréhez csatolt New Wave UP 213 lézerablációs feltét alkalmazásával történtek, ami ,in-situ” és majdnem roncsolásmentes, ppm $(\mathrm{mg} / \mathrm{kg})$ szintú nyomelem-meghatározást tett lehetővé. Li-7, Be-9, B-11, Na-23, Al-27, Si-29, P-31, K-39, Ca-43, Ti-48, Ti-49, Fe-57, Ga-71, Ge-74, Y-89, Ba-138 és Pb-208 izotópok kerültek mérésre. Közülük a Si koncentrációjának meghatározása normálás céljából történt, ezért nem szerepel az eredmények között. A Be, B, Ca, Fe, Ga, Ge, Y és Pb koncentrációja a kimutatási határ alatt volt. A mérések során az izotópok koncentrációjának időbeli változását monitorozva a karakteres koncentrációváltozások zárványok jelenlétére utalnak. A zárványok felismerését az előzetes mikroszkópos átnézés is segítette. A közölt mérési eredmények a kvarcok zárványmentes helyein készültek. Külsô sztenderdként a NIST610et használtuk, belső sztenderdként a Si-29-et. Kontrollanyagként a BCR-2G és GSE-1G sztenderdeket mértük visz-sza, amelyek referenciaértékei megbízhatóan 10\%-on belül $(0,28-9,97 \%)$ visszajöttek, kivéve a foszfort, de az is $29 \%$ relatív hiba alatt maradt. A kimutatási határ Pettke et al. (2012) módszerével került kiszámításra. A kiértékelések SILLS programmal történtek a kiugró értékek (spike-ok) eltávolításával.

Mikro-FTIR mérések húsz kvarcszeparátumon készültek egyrészt a Nemzeti Szakértôi és Kutató Központban, másrészt az MTA Csillagászati és Földtudományi Kutatóközpont Földtani és Geokémiai Intézetében Bruker Hyperion 1000 infravörös mikroszkóphoz csatlakoztatott Bruker Vertex 70 spektrométerrel. A legtöbb kvarcszeparátumból 5, néhány esetben 6 vagy 2 szemcse mérése történt további előkészítés nélkül, $\mathrm{CaF}_{2}$ tárgylemezre helyezve. Négy kvarcszeparátum porított, majd fél órára szárítószekrénybe $\left(70-80^{\circ} \mathrm{C}\right)$ helyezett anyagán IR spektrometriai vizsgálat készült az MBFSZ Bruker Vertex 70 spektrométeréhez csatlakoztatott Bruker Platinum ATR-egységgel, MCT-B detektor alkalmazásával. A spektrumok kiértékelése OPUS® szoftverrel történt többek között KovÁcs et al. (2008) és SAMBRIDGE et al. (2008) eredményeinek figyelembevételével. A mikro-FTIR és IR spektrumok feldolgozása során az első lépés az atmoszferikus kompenzáció volt, ezután a megfelelô minőségú spektrumok átlagolása következett, az erôs vízgózjelet tartalmazó vagy kontaminált minták kizárásával. Majd az OPUS „,concave rubberband” háttér korrekcióját használtuk az átlagra (64 illesztési pont és 2 iteráció). A mikro-FTIR esetében az átlag „,szemcse” effektív vastagságának becslése a Si-O rezgések alatti terület alapján BiRó et al. (2016) módszerét felhasználva, a szerkezeti hidroxil abszolút mennyiségének meghatározása THOMAs et al. (2009), a molekuláris víz meghatározása KATS et al. (1962) kioltási együtthatói segítségével történt. A szerkezeti hidroxiltartalom meghatá- 
rozása esetében $\left(\mathrm{Si}^{4+} \rightarrow \mathrm{Al}^{3+}+\mathrm{H}^{+}\right)$a sávok integrálása 3462 és $3280 \mathrm{~cm}^{-1}$ közötti B típusú integrációval történt. A molekuláris víz koncentrációja zárványokban 3764 és 3000 cm-1 közötti B típusú integrállal került becslésre. A porított kvarcszeparátumokon végzett IR spektrometriai mérések kiértékelése során a relatív víztartalom meghatározása a 3728 és $3080 \mathrm{~cm}^{-1}$ közötti szakasz B típusú integrálásával számolt sávterület alapján történt. Azonban az ezt a szakaszt jellemzô rendkívül kis intenzitások miatt a mikro-FTIR mérések alapján elkülönített víztípusokat nem lehetett megfigyelni.

A kvarcok jellemzőit termoanalitikai elemzésekkel is vizsgáltuk huszonegy szeparátumon az MBFSZ NETZSCH STA 449 F5 Jupiter automata mintaváltós berendezésével a kvarc vizsgálatára alkalmas differenciális pásztázó kalorimetria (Differential Scanning Calorimeter, azaz DSC) módszerrel. A DSC mérésekkel az $\alpha$-kvarc és $\beta$-kvarc módosulatok közötti átmenetet vizsgáltuk, amely gyors endoterm reakció, és elvileg $573{ }^{\circ} \mathrm{C}$-on játszódik le (КоCH \& SzTRÓKAY 1967). Mivel az átalakulás reverzibilis, ezért a hútés során lezajló exoterm reakció DSC-jelei is detektálásra kerültek. A kvarc mellett megjelenő egyéb fázisok kimutatásához termogravimetriát (TG) alkalmaztunk. A kiértékelés során a berendezéshez kifejlesztett Proteus Analysis szoftvert használtuk.

Hat kvarcszeparátumon készült röntgen-pordiffrakciós elemzés, azokon amelyekről feltételezhető volt, hogy nem teljesen tiszták, és amelyekből elegendő anyag állt rendelkezésre a mérés elvégzéséhez. A felvételek az MBFSZ Röntgen Laboratóriumában Philips PW 1730 diffraktométerrel, XDB Power Diffraction Phase Analytical System 2.7 version számítógépes vezérlő rendszerrel készültek. A felvételi körülmények a következők voltak: $\mathrm{Ni}-\mathrm{Al}$ ötvözetből álló mintatartó, Cu-antikatód, $40 \mathrm{kV}$ és $30 \mathrm{~mA}$ csőáram, grafit monokromátor, goniométersebesség $2 \%$ perc, mérési tartomány $2-66^{\circ} 2 \Theta$. A diffraktogramok kiértékelését a PDF (Powder Diffraction File) adatbázis segítette. Az ásványos összetételt az egyes ásványokra jellemző reflexiók relatív intenzitása és az ún. kísérleti korund-faktorok (KLUG \& AlEXANDER 1954) alapján számítottuk. A mennyiségi összetételt az XDB Power Diffraction Phase Analytical System 2.7 szoftverrel értékeltük ki.

A képződmények radioaktív U-, Th- és K-koncentrációját gamma-spektrometriai mérések alapján határoztuk meg. Ehhez a minták előkészítése a magmás, metamorf és üledékes kőzetek esetében törésből, majd max. 1 mm-es méretre őrlésből és szárításból állt. Az üledékek esetében csak az 1 mm-nél nagyobb szemcséket kellett őrölni, majd az egész üledékanyagot szárítani. A mérések Canberra-Packard hordozható, nagy spektrális érzékenységú, folyékony nitrogénnel hútött HpGe félvezető detektorral készültek. Tizenkét minta Marinelli-edénybe töltve került lemérésre, a többi minta mennyisége csak kisebb mintatartó alkalmazását tette lehetővé. Az utóbbi kis tömegú minták U-, Th- és K-koncentráció-értékeinek kiszámítása szimulált hatásfokérték segítségével történt (THAMónÉ BozSó et al. 2017).

\section{Vizsgálati eredmények}

\section{Lumineszcens mérési eredmények}

A vizsgált képződményekből szeparált kvarcfrakciók tipikus OSL mérési görbéit a 2. ábra mutatja be. Az OSL intenzitások átlag értékeit és szórását a II. táblázat tartalmazza úgy, hogy a kezdeti 0,8 másodperc során mért lumineszcenciából a háttér kivonásra került. Eszerint a legerósebb OSL-lel ( 245 000 31 000) a Kállai Kavics Formáció Kisörsről gyújtött homokmintájának a kvarcszeparátuma

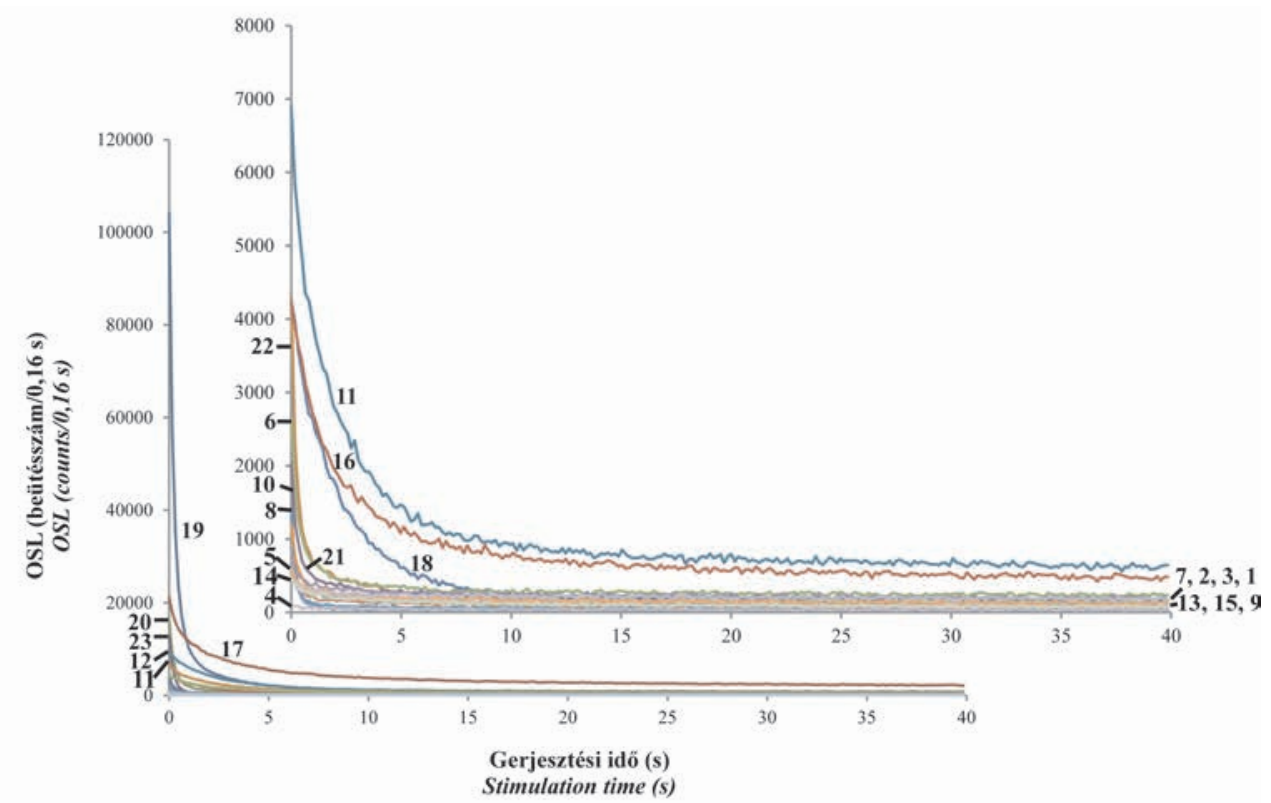

2. ábra. A vizsgált kvarcszeparátumok tipikus OSL szignáljai $280^{\circ} \mathrm{C}$-on történt megvilágítás, majd 16,6 Gy radioaktív besugárzás és $240^{\circ} \mathrm{C}$ előmelegítés után mérve (Mintakódok jelentése az I. táblázatban)

Figure 2. Typical OSL signals of the studied quartz separates after illumination on $280^{\circ} \mathrm{C}$, then $16.6 \mathrm{~Gy}$ irradiation and $240^{\circ} \mathrm{C}$ preheat (Meaning of code numbers is in Table I) 
II. táblázat. A vizsgált képződményekből szeparált kvarcok OSL intenzitása (n: lemért részminták száma, F: Formáció, T: Tagozat)

Table II. OSL intensity of quartz fractions of the studied rocks and sediments (n: number of the measured aliquots, F: Formation, T: Member)

\begin{tabular}{|l|c|c|}
\hline \multicolumn{1}{|c|}{$\begin{array}{c}\text { Minta } \\
\text { Sample }\end{array}$} & n & $\begin{array}{c}\text { OSL intenzitás } \\
\text { OSL intensity }\end{array}$ \\
\hline Tolvajárki Leukofillit T. (Sopron) & 5 & $592 \pm 192$ \\
\hline Sopronbánfalvi Gneisz F. (Sopron) & 5 & $1271 \pm 273$ \\
\hline Vöröshídi Csillámpala F. (Brennbergbánya) & 5 & $2828 \pm 1333$ \\
\hline Mórágyi Gránit F. (Mórágy) & 5 & $373 \pm 149$ \\
\hline Velencei Gránit F. (Sukoró) & 5 & $8432 \pm 7598$ \\
\hline Balatonfelvidéki Homokkö F. (Balatonrendes) & 5 & $6547 \pm 1886$ \\
\hline Bajnai T. (Lábatlan) & 5 & $1384 \pm 254$ \\
\hline Tokodi F. idösebb része (Tatabánya) & 5 & $2979 \pm 2435$ \\
\hline Tokodi F. fiatalabb része (Tokodaltáró) & 5 & $1123 \pm 285$ \\
\hline Hárshegyi Homokkö F. (Budapest) & 5 & $2213 \pm 626$ \\
\hline Törökbálinti Homokkõ F. (Tokodaltáró) & 5 & $26733 \pm 11577$ \\
\hline Törökbálinti Homokkö (Göd) & 5 & $16216 \pm 13827$ \\
\hline Csatkai F. (Mór) & 5 & $4797 \pm 3223$ \\
\hline Gyulakeszi Riolittufa F. (Kazár) & 5 & $2367 \pm 1723$ \\
\hline Kazári Homokkõ T. (Kazár) & 3 & $968 \pm 1147$ \\
\hline Tari Dácittufa F. (Göd) & 5 & $8705 \pm 6458$ \\
\hline Tari Dácittufa F. (Fót) & 5 & $36489 \pm 20429$ \\
\hline Tokaji Vulkanit F. (Sárospatak) & 5 & $244843 \pm 30924$ \\
\hline Kállai Kavics F. (Kisörs) & 5 & $40309 \pm 11138$ \\
\hline Kállai Kavics F. (Fehérvárcsurgó) & $5119 \pm 1301$ \\
\hline Tihanyi T. (Fonyód) & $583 \pm 2170$ \\
\hline Bükkaljai Lignit T. (Bükkábrány) & 5 & \\
\hline Zagyvai F. (Veresegyház) & 59864 \\
\hline
\end{tabular}

rendelkezik. Erős, fényes OSL-t (átlagosan 26 700-40 300) adnak a kvarcok a Kállai Kavics Formáció fehérvárcsurgói homokjában, a Tari Dácittufa fóti mintájában és a Törökbálinti Homokkő mintáiban. Közepes erősségû (átlagosan 2600-9800) az optikailag gerjesztett lumineszcenciája a kvarcoknak a Tokaji Vulkanit riolitban előforduló hidrokvarcitjában (Sárospatak), a Tari Dácittufa gödi mintájában, a Velencei Gránitban (Sukoró), a Zagyvai Formációban (Veresegyház), a Balatonfelvidéki Homokkőben (Balatonrendes) és a Bükkaljai Lignit Tagozat homokjában (Bükkábrány). A többi képződményből szeparált kvarcok csak gyenge, halvány OSL fényúek. A leggyengébb az OSL-je a Mórágyi Gránit (Mórágy) és a Tolvajárki Leukofillit (Sopron) kvarcszemcséinek. Annak ellenére, hogy az egyes kvarcszeparátumokból lemért kis részminták nagyjából ugyanakkora tömegúek voltak, az OSL intenzitásuk nagy szórást mutatott (II. táblázat).

Az OSL mérési görbék lefutása a normalizált görbék segítségével (elektronikus melléklet 1. ábra) is összehasonlítható (amikor az egyes OSL szignálok kezdeti értékét 1nek vettük, és ahhoz viszonyítottuk a görbe további méréspontjainak értékeit). Eszerint a Zagyvai, a Kállai, a Csat- kai Formációk és a Bükkaljai Lignit homokja, valamint a Hárshegyi Homokkő kvarcszeparátumainak a lumineszcenciája csökken a leggyorsabban (elektronikus melléklet 1 . ábra A diagramja), ami kedvező a kormeghatározás szempontjából. A kvarcszeparátumaink OSL szignáljainak komponensekre bontása (dekonvolúciója) alapján kiderült, hogy a feljebb említett leggyorsabban csökkenó lumineszcenciát adó minták OSL-jében a gyors komponens részaránya 82-93\%, a közepes komponensé 6-12\%. Az OSL leglassabb csökkenését és a mérési idő késôi szakaszában is arányaiban magas szintjét a Mórágyi Gránit, a Tolvajárki Leukofillit és a Vöröshídi Csillámpala kvarcszeparátumainál lehetett megfigyelni. Ezekben a gyors komponens részaránya kisebb volt (18-45\%). Ugyanakkor a Tokaji Vulkanit és a Tokodi Formáció fiatalabb részének kvarcszeparátumai lassan csökkenő OSL jelet adtak annak ellenére, hogy a gyors OSL komponens aránya elérte bennük a $80 \%$-ot.

A vizsgált minták tipikus növekedési görbéi a 3. ábrán láthatók. A kvarcszeparátumok zömére az OSL fokozatos növekedése jellemző az egyre nagyobb radioaktív besugárzások hatására (3. ábra A). Néhány minta azonban kezdeti igen gyors növekedést mutatott, majd szinte leállt a növekedés (3. ábra B), ilyenek a Sopronbánfalvi Gneisz, a Hárshegyi Homokkő, a Csatkai Formáció és a Tokaji Vulkanit kvarcszeparátumai. A többi mintától teljesen eltérően viselkedett a Mórágyi Gránit kvarca, amely nagyon gyenge és alig változó OSL-t adott az egyre növekvő radioaktív besugárzások után.

A növekedési görbék előállítása során a szeparátumok „természetes” dózisának mérése alapján kiderült, hogy a szokásos laborvilágítás mellett végzett mintaelőkészítés után is maradt valamennyi egyenérték dózis $\left(D_{\mathrm{e}}\right)$ a kvarcokban, vagyis a lumineszcenciájuk nem nullázódott le teljesen a fény hatására, mivel az OSL-ért felelős csapdáik nem ürültek ki teljesen. A kvarcszeparátumokban a fénynél végzett mintaelőkészítés után 0,08 és 12,28 Gy közötti egyenérték dózis maradt. A legkisebb, 0,7 Gy alatti értékek a Hárshegyi Homokkő, a Zagyvai, a Kállai Kavics és a Tokaji Vulkanit Formációk kvarcaiban jelentkeztek. A legnagyobb maradék egyenérték dózissal a Tolvajárki Leukofillit, a Csatkai Formáció és a Velencei Gránit kvarcszemcséi rendelkeztek.

A dózisvisszamérési teszt eredményei szerint a vizsgált kvarcszeparátumok közül csak a Kállai Kavics homokjai, a Csatkai Formáció homokja, a Hárshegyi Homokkő, a Törökbálinti Homokkő, a Zagyvai Formáció és a Tokodi Formáció fiatalabb részéből gyújtött minta kvarcai megfelelőek, mivel ezek esetében a mért dózis és a besugárzási

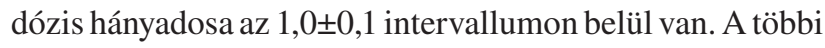
kvarcszeparátum 0,28 és 0,90 , illetve 1,10 és 2,53 közötti értékeket adott.

Az infravörös-teszt alapján a legtöbb szeparátum teljesen tiszta kvarcnak bizonyult, de voltak kissé szennyezett minták (Velencei Gránit, Tokodi Formáció, Bajnai Tagozat, Tihanyi Tagozat, Zagyvai Formáció, Tolvajárki Leukofillit kvarcszeparátumai), és a sort a Mórágyi Gránitból szeparált kvarcfrakció zárja, amely a legkevésbé tiszta. 

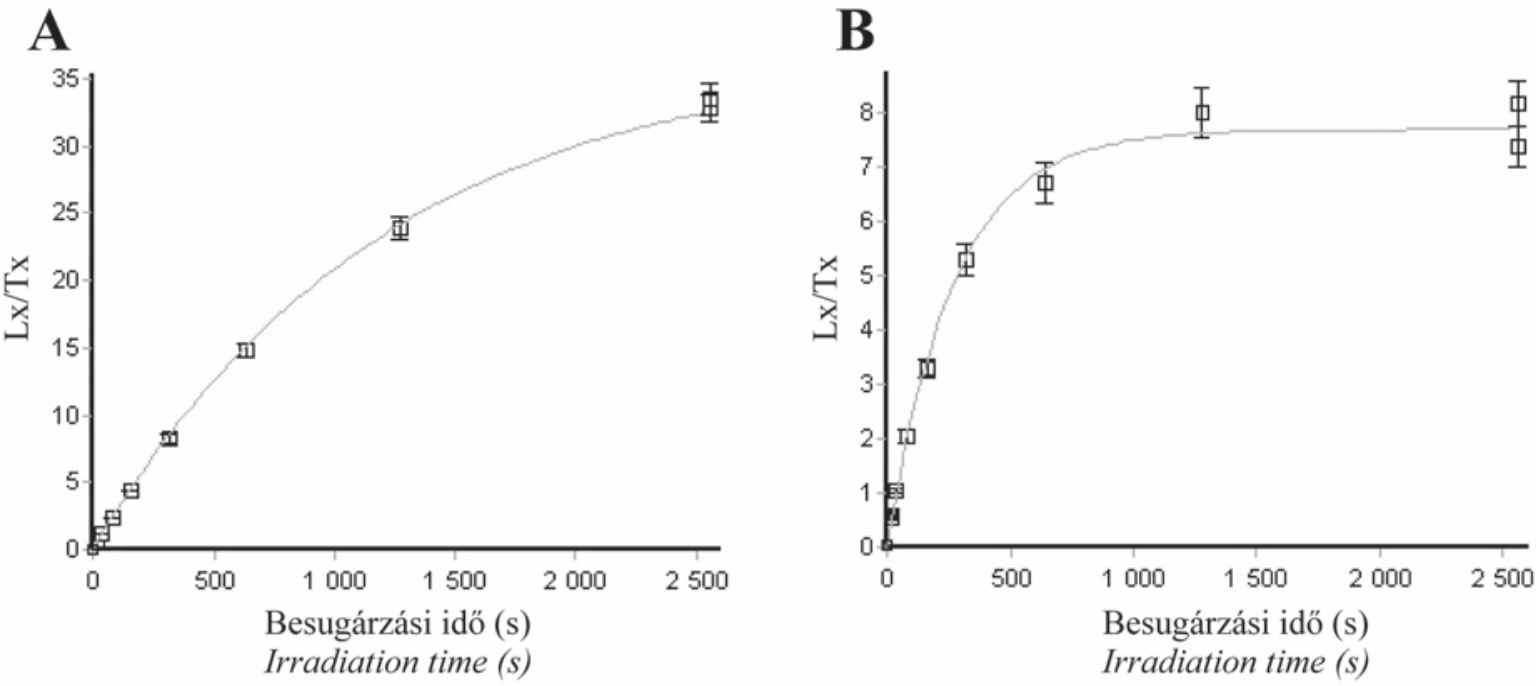

3. ábra. A vizsgált kvarcszeparátumok tipikus növekedési görbéi

A) fokozatosan növekvő görbe, amely a minták többségére jellemző a Zagyvai Formáció kvarcának példáján; B) eleinte gyorsan növekvő, majd alig változó növekedési görbe, amely a kvarc viszonylag kis radioaktív sugárdózis hatására történő telítődésével jár a Sopronbánfalvi Gneisz, a Hárshegyi Homokkő, a Csatkai Formáció, és a Tokaji Vulkanit Formáció kvarcszeparátumai esetében, a Hárshegyi Homokkő kvarcának példáján. 1 s besugárzási idő 0,8 Gy dózisnak felel meg

Figure 3. Typical OSL growth curves of the studied quartz separates

A) gradually increasing curve, which characterises most of the samples, example is the quartz of the Zagyva Formation; B) first quickly increasing then very slightly changing growth curve whith the saturation of the quartz due to relatively low radioactive radiation dose in the case of the quartz separates of the Sopronbánfalva Gneiss, Hárshegy Sandstone, Csatka Formation and Tokaj Volcanite Formation, example is the quartz of the Hárshegy Sandstone. $1 \mathrm{~s}$ irradiation time corresponds to $\sim 0.8$ Gy dose

Az érzékenységváltozás vizsgálatának eredményei szerint a kis OSL intenzitást adó Velencei Gránit kvarcának az érzékenysége ingadozó volt (4. ábra). A közepes OSL intenzitású Tokaji Vulkanitból való hidrokvarcit kvarcának érzékenysége a többszöri megvilágítás, besugárzás és melegítés után kissé növekvő tendenciát mutatott, míg a fényes OSL-t adó Tari Dácittufa kvarca esetében alig lehetett érzékenységváltozást tapasztalni.

\section{Polarizációs mikroszkópos vizsgálati eredmények}

A polarizációs mikroszkópos vizsgálat szerint a szeparátumokban a kvarc monokristályok domináltak, kivéve a Tokaji Vulkanit hidrokvarcitjának szeparátumát, amely főként mikrokristályos kvarcból állt. Alárendelten polikristályos kvarcszemcsék is megjelentek az üledékes minták nagy részében, legnagyobb arányban a Hárshegyi Homokkő szeparátumában. Jellegzetes gömbölyú formájú, felületükön visszaoldott (rezorbeált) tufa eredetú kvarcok is előfordultak a vulkanitok szeparátumain kívül a Törökbálinti Homokkő mintáiban, a Bükkaljai Lignit homokjában és a Csatkai Kavics homokjában.

A kvarcszemcsék nagy része zárványmentes volt, de apró (5-10 $\mu \mathrm{m}$-es) opak zárványokat tartalmazók minden szeparátumban akadtak. Előfordultak nagyobb ( $>50 \mu \mathrm{m}-$ es) opakásvány zárványok is (Csatkai Formáció, Tari Dácittufában fóti mintája, Kállai Kavics fehérvárcsurgói homokja, Újfalui Homokkő mintái, Zagyvai Formáció homokja). Az apró zárványok között cirkont (Tokodi Formáció idősebb része, Törökbálinti Homokkő, Csatkai Formáció, Gyulakeszi Riolittufa, Tari Dácittufa, Kállai Kavics
4. ábra. Néhány kvarcszeparátum érzékenység-változása többszöri, $280^{\circ} \mathrm{C}$-on történt kék fényủ megvilágítás, azonos dózisú ( $26 \mathrm{~Gy})$ radioaktív besugárzás és előmelegités $\left(260^{\circ} \mathrm{C}\right)$ hatására

Figure 4. Sensitivity changes of a few quartz separates after repeated blue light illumination on $280^{\circ} \mathrm{C}$, irradiations with the same dose (26 Gy) and preheat $\left(260^{\circ} \mathrm{C}\right)$ 
fehérvárcsurgói homokja), rutilt (Csatkai Formáció, Tari Dácittufa fóti mintája, Újfalui Homokkő mintái), csillámot (Tolvajárki Leukofillit), földpátot (Tari Dácittufa fóti mintája) és kianitot (Zagyvai Formáció) lehetett azonosítani.

Kevés muszkovit szennyezte a szeparátumokat a Tolvajárki Leukofillit, a Sopronbánfalvi Gneisz, a Vöröshídi Csillámpala, a Mórágyi Gránit és a Tokodi Formáció fiatalabb mintája esetében. Bontott földpátokat a Vöröshídi Csillámpala, a Mórágyi Gránit, a Törökbálinti Homokkő (Tokodaltáró), a Csatkai Formáció, a Tari Dácittufa (Göd), a Tihanyi Tagozat és a Zagyvai Formáció szeparátumai tartalmaztak. Kőzetüveg a Tari Dácittufa fóti mintájában, kőzettöredékek a Vöröshídi Csillámpala, a Tokodi Formáció fiatalabb mintája, a Csatkai Formáció, a Kállai Kavics kisörsi homokja, a Bükkaljai Lignit homokja és a Zagyvai Formáció szeparátumaiban fordultak elő.

\section{LA-ICP-MS mérési eredmények}

A múgyantába ágyazott, megcsiszolt és polírozott kvarcszemcse metszeteien készült LA-ICP-MS mérések eredményei szerint Li, Na, Al, P, K, Ti és Ba szennyezi az általunk vizsgált képződmények kvarcszemcséit. Ezek koncentrációja egy-egy kvarcszeparátumon belül több-kevesebb szórást mutat (elektronikus melléklet I. táblázat).

A mérési eredmények szerint az átlagértékeket tekintve a kimutatott szennyező elemek legnagyobb együttes koncentrációja (átlagosan 820-970ppm) a Mórágyi Gránitból, a Tokodi Formáció idősebb részéből, a Tolvajárki Leukofillitből, a Vöröshídi Csillámpalából és a Hárshegyi Homokkőből szeparált kvarcszemcsékre jellemzô. Mennyiségileg a legkevesebb szennyezőt (átlagosan 230-270 ppm) a Zagyvai Formáció és a Tari Dácittufa mintáinak kvarcszemcséi tartalmazták.

\section{Infravörös spektrometriai mérési eredmények}

A mikro-FTIR mérések során a vizsgált kvarcszemcsékben a leggyakoribb spektrális bélyeg a $\mathrm{Si}^{4+}$-iont helyettesítő $\mathrm{Al}^{3+}+\mathrm{H}^{+}$ volt, amelyhez a 3420, 3380 és $3320 \mathrm{~cm}^{-1}$-nél jelentkező triplet köthetô (szerkezeti hidroxil, ahol a $\mathrm{H}^{+}$a tetraéder csúcsán lévő oxigénekhez kapcsolódik, és hidroxil gyököt hoz létre). A szerkezeti hidroxil pontos becslését néhány minta esetében a molekuláris víz széles sávjai zavarták és vezettek a túlbecsléséhez. A másik gyakori komponens a 3800-3000 $\mathrm{cm}^{-1}$ között jelentkező hosszú elnyúlt elnyelési sávval megjelenô mole- kuláris víz, amely (nano-)zárványokban található. Pontos becslését az atmoszferikus interferencia folyamán 3500-nál magasabb hullámszámnál megjelenő „fésűs” vízgőz eredetû sávok befolyásolták. A harmadik valószínú előfordulása a víznek a $3630 \mathrm{~cm}^{-1}$-nél megjelenő sáv, amely feltehetően valamilyen víztartalmú ásványhoz (agyagásvány, csillám) kapcsolódik, és néhány minta esetében kifejezetten nagy intenzitással jelentkezik (Tolvajárki Leukofillit, Hárshegyi Homokkő, Sopronbánfalvi Gneisz).

A vizsgált minták kvarcszemcséinek normalizált mikroFTIR spektrumait az 5. ábra mutatja, a spektrumok menynyiségi kiértékelését a III. táblázat tartalmazza. A minták közül jelentôs AlOH szerkezeti hidroxiltartalommal rendelkeznek a következő képződményekból való kvarcok: Tokaji Vulkanit hidrokvarcitja (25 ppm), Balatonfelvidéki Homokkő (25 ppm), Kállai Kavics kisörsi homokja (21 ppm), Kazári Homokkő (17 ppm), Tari Dácittufa gödi mintája (16 ppm), és Kállai Kavics fehérvárcsurgói homokja (15 ppm). A többi mintában kevesebb az $\mathrm{AlOH}$ szerkezeti hidroxil, illetve a kimutatási határ alatt van, ami esetünkben kb. 6 ppm. Bár a III. táblázat szerint a Tokodi Formáció fiatalabb részéből (30 ppm) és a Zagyvai Formációból (20ppm) vizsgált kvarcszemcsék is jelentős mennyiségú $\mathrm{AlOH}$ szerkezeti hidroxilt tartalmaznak, azonban ezek durván túlbecsült értékek, mert a jelentős molekuláris víztartalom miatt az integrálási módszerből eredően nagyobb területek adódtak. A normalizálás után valójában ezeken a spektrumokon alig felismerhetően jelentek meg a 3420, 3380 és 3320 cm-1 sávok, azaz nagyjából inkább a kimutatási határ környékén voltak.

A molekuláris víztartalom esetében három minta kvarc-

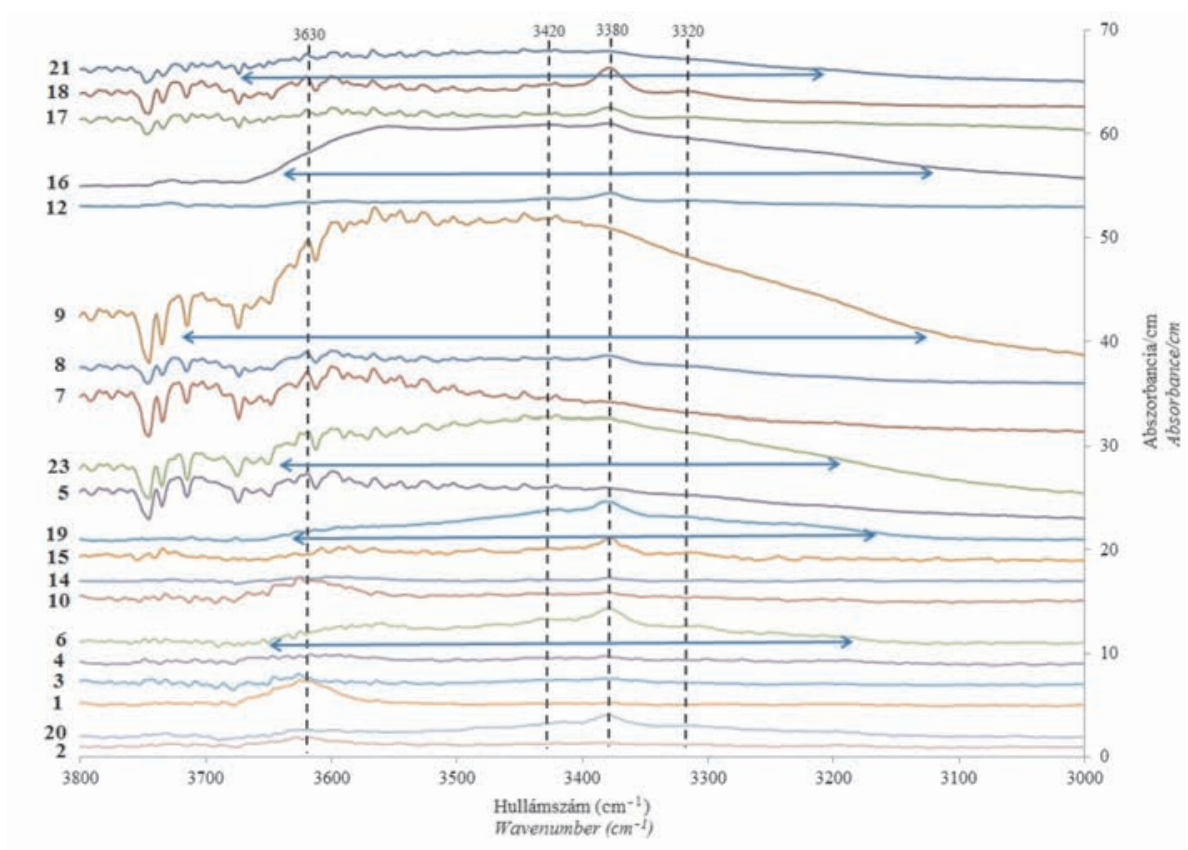

5. ábra. A vizsgált képződmények kvarcszemcséinek normalizált mikro-FTIR spektrumai (Jellemző elnyelési sávok: 3420, 3380 és $3320 \mathrm{~cm}^{-1}$ - AlOH szerkezeti hidroxil; $3630 \mathrm{~cm}^{-1}$ - víztartalmú szilikátok; nyilak molekuláris víz; mintakódok jelentése az I. táblázatban)

Figure 5. Normalized Micro-FTIR spectra of the quartz grains from the studied formations (Characteristic absorbance bands: 3420,3380 and $3320 \mathrm{~cm}^{-1}$ - AlOH structural hydroxyl; $3630 \mathrm{~cm}^{-1}$ - hydrous silicate; arrows - molecular water, meaning of code numbers is in Table I) 
III. táblázat. A vizsgált képződmények kvarcainak $\mathrm{AlOH}$ szerkezeti hidroxil- és víztartalma a mikro-FTIR mérési eredmények alapján

Table III. AlOH structural hydroxyl and water contents of quartz in the studied formations based on Micro-FTIR measurements

\begin{tabular}{|l|c|c|}
\hline \multicolumn{1}{|c|}{$\begin{array}{c}\text { Minta } \\
\text { Sample }\end{array}$} & \multicolumn{2}{c|}{$\begin{array}{c}\text { Koncentráció* } \\
\left(\mathrm{H}_{2} \mathrm{O} \text { ppm tömeg\%) }\right. \\
\text { Concentration } \\
\left(\mathrm{H}_{2} \text { O ppm wt\%) }\right.\end{array}$} \\
\cline { 2 - 3 } & $\mathrm{OH}^{\text {**** }}$ & $\mathrm{H}_{2} \mathrm{O}^{\text {w** }}$ \\
\hline Tolvajárki Leukofillit T. & 0 & 22 \\
\hline Sopronbánfalvi Gneisz F. & 4 & 18 \\
\hline Vöröshídi Csillámpala F. & 5 & 5 \\
\hline Mórágyi Gránit F. & 6 & 28 \\
\hline Velencei Gránit F. & 6 & 77 \\
\hline Balatonfelvidéki Homokkö F. & 25 & 81 \\
\hline Bajnai T. (Dorogi F.) & 4 & 61 \\
\hline Tokodi F. idösebb része & 11 & 65 \\
\hline Tokodi F. fiatalabb része & $(30)$ & 517 \\
\hline Hárshegyi Homokkö F. & 6 & 23 \\
\hline Törökbálinti Homokkö F. (Göd) & 9 & 30 \\
\hline Gyulakeszi Riolittufa F. & 4 & 7 \\
\hline Kazári Homokkö T. & 17 & 27 \\
\hline Tari Dácittufa F. (Göd) & 16 & 273 \\
\hline Tari Dácittufa F. (Fót) & 9 & 53 \\
\hline Tokaji Vulkanit F. & 25 & 55 \\
\hline Kállai Kavics F. (Kisörs) & 21 & 110 \\
\hline Kállai Kavics F. (Fehérvárcsurgó) & 15 & 51 \\
\hline Tihanyi T. & 10 & 105 \\
\hline Zagyvai F. & $(20)$ & 276 \\
\hline
\end{tabular}

Jelmagyarázat: dőlt betủ: kimutatási határ alatti érték; zárójel: valószínűleg túlbecsült érték; *: koncentrációk 20\% bizonytalansággal; **:

a hidroxil kimutatási határa $\sim 6 \mathrm{ppm}$ tömeg\%; ***: a (nano-) zárványokban lévő molekuláris víz kimutatási határa $\sim 50$ ppm tömeg\%.

Legend: italics: below the limit of detection; brackets: probably overestimated value, *: the concentrations bear $\sim 20 \%$ uncertainty; **: detection limit for structural hydroxyl is $\sim 6 p p m w t \% ;{ }^{* * *}$ : detection limit for molecular water in (nano-) inclusions is $\sim 50 \mathrm{ppm} w \mathrm{wt} \%$.

szemcséi mutattak kifejezetten nagy értéket. Ezek a Tokodi Formáció fiatalabb részéből (517 ppm), a Zagyvai Formációból (276ppm) és a Tari Dácittufa gödi mintájából (273 ppm) valók. Viszonylag nagy a víztartalma a kvarcszemcséknek a Kállai Kavics kisörsi homokjában (110ppm), az Újfalui Homokkő Tihanyi Tagozatában (105 ppm) és a Balatonfelvidéki Homokkőben (81 ppm) is. A molekuláris víz kimutatási határa jelen esetben 50 ppm környékén van, így a többi mintában a kimutatási határ közeliek vagy az alattiak a koncentrációk.

A néhány porított kvarcszeparátumon végzett IR spektrometriai mérés alapján a $\mathrm{H}_{2} \mathrm{O}$ legnagyobb sávterülettel a Bükkábrányi Lignit Tagozat és a Csatkai Formáció homok- jainak kvarcfrakciójában jelentkezett (a görbe alatti terület 0,45 és 0,25). Az Újfalui Homokkő Tihanyi Tagozata esetében kisebb érték adódott $(0,08)$, míg a Törökbálinti Homokkő Tokodaltárónál gyújtött homokjának kvarcfrakciója nem adott értékelhető eredményt. Eszerint az első két kvarcszeparátumban jelentősebb a víztartalmú fázisok (agyagásvány vagy csillám) jelenléte, a másik két mintában ezek koncentrációja a kimutatási határ közelében vagy az alatt van.

\section{Termoanalitikai mérési eredmények}

A minták nagy részének DSC mérési görbéi nagyon hasonló lefutásúak (elektronikus melléklet 2. ábra), de a Tari Dácittufa mintái és a Tokaji Vulkanit kvarcfrakciója eltérést mutat, aminek az az elsôdleges oka, hogy ezekből a többi mintához képest csak kisebb mintamennyiség állt rendelkezésre a mérés elvégzéséhez. A termoanalitikai mérések során a két kvarcváltozat közötti átmenet az elméleti értéktől kissé eltérőnek, 0,2-0,5\%-kal nagyobbnak adódott.

A termogravimetriai mérések eredményei szerint a kvarcszeparátumok zöme csak kvarcot tartalmaz, míg egyes minták nem teljesen tiszták, mivel víz, hidroxil és más, hő hatására illó fázis is kimutatható volt belőlük. Ezek elsősorban agyagásványok jelenlétével függenek össze. Ilyen a Törökbálinti Homokkő gödi mintája $\left(4,12 \% \mathrm{H}_{2} \mathrm{O} ; 1,78 \%\right.$ $\left.\mathrm{OH}^{-}\right)$, a Mórágyi Gránit $\left(3,08 \% \mathrm{H}_{2} \mathrm{O} ; 2,45 \% \mathrm{OH}^{-} ; 0,13 \%\right.$ illó), a Velencei Gránit $\left(0,88 \% \mathrm{H}_{2} \mathrm{O} ; 4,07 \% \mathrm{OH}^{-}\right)$és a Balatonfelvidéki Homokkő $\left(1,09 \% \mathrm{H}_{2} \mathrm{O}\right)$ kvarcszeparátuma.

\section{Röntgen-pordiffrakciós mérési eredmények}

A vizsgálatra kiválasztott, feltételezhetően nem teljesen tiszta hat szeparátum közül négyben a kvarc részaránya elérte, illetve meghaladta a 92\%-ot (Balatonfelvidéki Homokkő 96\%, Tolvajárki Leukofillit 95\%, Hárshegyi Homokkő 93\%, Velencei Gránit 92\%). Kisebb kvarctartalommal rendelkezett a Mórágyi Gránit (80\%) és a Törökbálinti Homokkő (77\%) szeparátuma. Az utóbbi két mintában a kvarcfrakciót elsôsorban szmektit, illetve csillám szennyezte, valamint klorit, amfibol és kérdéses ásványok (anatáz?, krisztobalit?, osarizawait?, bassanit?) is előfordultak bennük. A kérdéses ásványok jelenlétének igazolására további vizsgálatok szükségesek (pl. elektronmikroszkópos vizsgálat).

\section{Gamma-spektrometriai mérési eredmények}

A vizsgált kvarcokat befoglaló mintákon végzett gamma-spektrometriai mérések alapján számított U-, Th- és Kkoncentrációértékeket a IV. táblázat tartalmazza. Az urán részaránya a Kazári Homokkőben a legnagyobb, 8,66 ppm, majd a Vöröshídi Csillámpala, a Gyulakeszi Riolittufa, a Balatonfelvidéki Homokkő, a Mórágyi és a Velencei Gránit, illetve a Tolvajárki Leukofillit következik (4,19-6,32 ppm). A legkisebb U-koncentrációk a Bajnai Tagozat homokjára, a Zagyvai Formációra és a Tihanyi Tagozatra jellemzők (0,50-1,56 ppm). A vizsgált minták közül a legnagyobb tóriumtartalom (42,42 ppm) a Mórágyi Gránitban jelent- 
IV. táblázat. A vizsgált képződmények U-, Th- és K-koncentrációja a gamma-spektrometriai mérések alapján

Table IV. U, Th and K content of the studied formations based on gamma spectromerty measurements

\begin{tabular}{|c|c|c|c|c|}
\hline $\begin{array}{l}\text { Minta } \\
\text { Sample }\end{array}$ & $\begin{array}{c}\text { Tömeg } \\
\text { Mass } \\
\text { (g) }\end{array}$ & $\begin{array}{c}\mathrm{U} \\
(\mathrm{ppm})\end{array}$ & $\begin{array}{c}\text { Th } \\
(\mathrm{ppm})\end{array}$ & $\begin{array}{c}\text { K } \\
\text { (tömeg \%) }\end{array}$ \\
\hline Tolvajárki Leukofillit T. & 64,1 & $4,19 \pm 0,17$ & $9,36 \pm 0,47$ & $4,33 \pm 0,04$ \\
\hline Sopronbánfalvi Gneisz F. & 54,8 & $2,73 \pm 0,12$ & $3,31 \pm 0,70$ & $6,41 \pm 0,06$ \\
\hline Vöröshídi Csillámpala F. & 57,6 & $6,32 \pm 0,21$ & $24,70 \pm 0,96$ & $3,86 \pm 0,04$ \\
\hline Mórágyi Gránit F. & 50,4 & $4,69 \pm 0,36$ & $42,42 \pm 1,02$ & $4,07 \pm 0,04$ \\
\hline Velencei Gránit F. & 998,0 & $4,67 \pm 0,03$ & $23,14 \pm 0,11$ & $3,78 \pm 0,02$ \\
\hline Balatonfelvidéki Homokkő F. & 60,3 & $5,12 \pm 0,20$ & $14,80 \pm 0,68$ & $0,94 \pm 0,01$ \\
\hline Bajnai T. & 1009,0 & $0,5 \pm 0,01$ & $1,52 \pm 0,04$ & $0,80 \pm 0,01$ \\
\hline Tokodi F. idősebb része & 754,0 & $3,64 \pm 0,03$ & $6,85 \pm 0,07$ & $0,71 \pm 0,01$ \\
\hline Tokodi $\mathrm{F}$. fiatalabb része & 827,0 & $1,95 \pm 0,02$ & $4,42 \pm 0,06$ & $0,69 \pm 0,01$ \\
\hline Hárshegyi Homokkő F. & 76,7 & $1,95 \pm 0,09$ & $2,85 \pm 0,31$ & $0,41 \pm 0,00$ \\
\hline Törökbálinti Homokkő F. (Tokodaltáró) & 813,8 & $1,83 \pm 0,02$ & $4,97 \pm 0,08$ & $1,00 \pm 0,01$ \\
\hline Törökbálinti Homokkő F. (Göd) & 572,2 & $2,86 \pm 0,03$ & $8,32 \pm 0,10$ & $1,48 \pm 0,02$ \\
\hline Csatkai F. & 589,8 & $2,7 \pm 0,03$ & $6,38 \pm 0,12$ & $1,23 \pm 0,02$ \\
\hline Gyulakeszi Riolittufa F. & 62,2 & $5,9 \pm 0,20$ & $25,53 \pm 0,70$ & $3,13 \pm 0,03$ \\
\hline Kazári Homokkő T. & 76,5 & $8,66 \pm 0,23$ & $24,53 \pm 0,66$ & $1,70 \pm 0,02$ \\
\hline Tari Dácittufa F. (Göd) & 444,2 & $3,17 \pm 0,04$ & $12,81 \pm 0,13$ & $1,39 \pm 0,02$ \\
\hline Tari Dácittufa F. (Fót) & 699,3 & $2,46 \pm 0,03$ & $13,31 \pm 0,11$ & $1,77 \pm 0,02$ \\
\hline Kállai Kavics F. (Kisörs) & 92,8 & $2,82 \pm 0,13$ & $3,93 \pm 0,27$ & $0,40 \pm 0,04$ \\
\hline Kállai Kavics F. (Fehérvárcsurgó) & 83,7 & $1,87 \pm 0,11$ & $1,72 \pm 0,17$ & $0,58 \pm 0,01$ \\
\hline Tihanyi T. & 800,4 & $1,56 \pm 0,02$ & $5,20 \pm 0,07$ & $1,19 \pm 0,01$ \\
\hline Bükkaljai Lignit T. & 894,7 & $2,59 \pm 0,03$ & $3,72 \pm 0,07$ & $1,24 \pm 0,01$ \\
\hline Zagyvai F. & 874,4 & $1,23 \pm 0,02$ & $3,81 \pm 0,05$ & $0,75 \pm 0,01$ \\
\hline
\end{tabular}

anyag egységnyi radioaktív sugárdózis hatására adott lumineszcens fényének az intenzitásával fejezhető ki, pl. SHARMA et al. 2017). A magmás és metamorf kőzetek kvarcai esetében is nagy változékonyságot figyeltek meg a kvarcszemcsék lumineszcens tulajdonságaiban, lumineszcens érzékenységében (RHODES 2007). Sőt, egyetlen kvarckristály kisebb darabjainak OSL jellemzői, illetve OSL érzékenysége is nagy különbségeket mutatott (ADAMEIC 2000). Ennek a jelenségnek az okát az üledékek esetében a kvarcszemcsék egyenkénti OSL mérésével derítették ki. DuLLER et al. (2000) megállapították, hogy az OSL változékonyságát a szemcsék lumineszcens érzékenységének és telítődési jellemzőinek változékonysága eredményezi. Esetükben a vizsgált kvarcszemcsék által kibocsátott lumineszcencia 95\%-a nagyjából a szemcsék 5\%-ától származott, vagyis arányaiban kevés kvarcszemcse adott lumineszcenciát.

Az általunk vizsgált kvarcszeparátumok felét nagy és közepes intenzitású OSL jellemez. Ezek főként üledékes képzôdmények (Kállai Kavics homokjai, Törökbálinti Homokkő, Zagyvai Formáció, Balatonfelvidéki Homokkő, Bükkaljai Lignit homokja), részben vulkanitok (Tokaji Vulkanit hidrokvarcitja, Tari Dácittufa mintái). Az említett üledékes képződmények közé többnyire azok tartoznak, amelyek többszöri üle-

kezett, amit a Gyulakeszi Riolittufa, a Vöröshídi Csillámpala, a Kazári Homokkő és a Velencei Gránit követ 23,14 és 25,53 ppm közötti koncentrációkkal. A Th a Bajnai Tagozatban és a Kállai Formáció fehérvárcsurgói üveghomokjában volt a legkevesebb. A káliumtartalmat tekintve a Sopronbánfalvi Gneisz vezeti a sort 6,41 tömeg\%-kal, amit a Tolvajárki Leukofillit, a Mórágyi Gránit, a Vöröshídi Csillámpala, a Velencei Gránit és a Gyulakeszi Riolittufa követ (3,13-4,33 tömeg\%). A Kállai Kavics homokjaiban és a Hárshegyi Homokkőben jelentkeztek a legkisebb K-koncentrációértékek.

\section{Diszkusszió}

A vizsgált képződményekből szeparált kvarcfrakciók nagyjából azonos tömegú kis részmintái változó intenzitású OSL-t adtak (II. táblázat). Ez nem meglepó az üledékek esetében, mivel számos mérési adat szerint az üledékek kvarcszeparátumaiból kivett részminták nagyon eltérő OSL érzékenységgel rendelkeznek (pl. MuRRAY \& WINTLE 2000, 2003). (A lumineszcens érzékenység az egységnyi tömegű dékes áthalmozódáson eshettek át a képződésük során. A gyenge, kis intenzitású OSL-t kibocsátó kvarcok metamorf és mélységi magmás kőzetekből valók, valamint a Gyulakeszi Riolittufából és egyes üledékes képződményekből.

Az OSL szignálokban a csapdák kiürülése, illetve a lumineszcens fény időbeni megjelenése és lecsengése alapján megkülönböztethetô gyors, közepes és lassú OSL komponens (SingARAYER \& BAILEY 2003), esetleg ultragyors és többféle lassú komponens (JAIN et al. 2003). Közülük a gyors, illetve ultragyors komponensek a legérzékenyebbek a fényre, ezért ezek jelennek meg legkorábban a megvilágítás hatásra, gyorsan lecsengenek, és termálisan stabilak. Emiatt az OSL gyors komponense a legalkalmasabb a kormeghatározásra (WintLeY \& MurRay 2006). Az OSL komponensek a lumineszcens érzékenységet is meghatározzák. Esetünkben az OSL szignálok komponensekre bontása igazolta, hogy azokban a kvarcokban, amelyeknek az OSL-je gyorsan csökkent, a gyors OSL komponens dominált (Zagyvai, Kállai és Csatkai Formációk homokjai, Bükkaljai Lignit homokja, Hárshegyi Homokkő kvarcszeparátumai). A gyors komponens nagy részaránya miatt ezek a kvarcok a legalkalmasabbak a kormeghatározásra. Ugyanakkor a las- 
san csökkenő szignálokban a közepes vagy lassú komponens volt túlsúlyban, ami kedvezőtlen a kvarcok kormeghatározása szempontjából. Ez a tendencia azonban nem érvényesült két kvarcszeparátum esetében (Tokaji Vulkanit és a Tokodi Formáció fiatalabb része) melyek lassan csökkenő OSL jelet adtak annak ellenére, hogy a gyors OSL komponens dominált a szignáljukban.

OSL mérési eredményeink összhangban vannak azokkal a korábbi megfigyelésekkel is, melyek szerint a különböző eredetû kvarcok lumineszcens emissziója eltérô (pl. RINK et al. 1993, Westaway 2009). Tsukamoto et al. (2011) Japánban előforduló gránitok és riolitok kvarcának OSL-jében csak néhány kőzetminta esetében találtak gyors komponenst, és megállapították, hogy ez a komponens nem feltétlenül a kvarc kristályosodása során létrejött ún. intrinsic hibákkal van kapcsolatban, hanem a késóbb kialakult csapdákkal. Viszont minden kôzetminta kvarca esetében detektáltak közepes komponenst, melyet a geológiai időn át stabil csapdákkal pl. szennyeződési centrumokkal hoztak kapcsolatba.

TOKUYASU et al. (2010) olyan ismert forráskőzetekből származó recens tengerparti üledékeket is találtak Japánban, amelyek kvarca nem adott OSL jelet. Egyes vulkáni kvarcok mérésekor csak közepes és lassú komponenst regisztráltak, ami a koruk alábecslését okozza. Olyan vulkáni eredetû kvarcokat is említettek, amelyek csapdáinak anomális töltésvesztése nehezíti a pontos kormeghatározást.

Az általunk vizsgált kvarcszeparátumok zöme az OSL növekedési görbéje alapján alkalmas a kormeghatározásra, mivel egyre növekvő radioaktív sugárzásdózisok hatására fokozatosan növekszik az OSL-jük, és viszonylag magas dózis hatására telítődnek a csapdáik. A Sopronbánfalvi Gneisz, a Hárshegyi Homokkő, a Csatkai Formáció és a Tokaji Vulkanit kvarcfrakciói azonban a kezdeti igen gyors OSL növekedés miatt már viszonylag kis radioaktív sugárdózis hatására telítődnek, vagyis a csapdáik teljesen feltöltődnek, és a telítési szint fölött a további besugárzás már nem okoz változást a lumineszcenciájukban, ami hátrányos a kormeghatározás szempontjából. A Mórágyi Gránit kvarcszemcséi pedig teljesen alkalmatlanok az OSL kormeghatározásra, mivel lumineszcenciájuk nem változik az egyre növekvő radioaktív besugárzások hatására.

A vizsgált kvarcszeparátumok zöme azért sem lenne jó a kormeghatározásra, mert rossz dózisvisszamérési arányt adott, mivel a mért dózis és a besugárzási dózis hányadosa az 1,0 $\pm 0,1$ intervallumon kívül esett. Ennek egyik oka az lehet, hogy ezeknek a kvarcoknak a lumineszcenciája fény hatására nem nullázódik le teljesen. Ugyanakkor a Kállai Kavics, a Csatkai Formáció, a Hárshegyi Homokkő, a Törökbálinti Homokkő, a Zagyvai Formáció és a Tokodi Formáció fiatalabb részéből gyújtött minta kvarcain megfelelő dózisvisszamérési arányt mértünk, ami ebből a szempontból alkalmassá tenné ooket a kormeghatározásra.

Az OSL mérések során az IR-teszt is jelezte, hogy néhány képződményből nem sikerült tiszta kvarcszeparátumot előállítanunk: Velencei Gránit, Tokodi Formáció, Bajnai Tagozat, Tihanyi Tagozat, Zagyvai Formáció, Tolvajárki Leukofillit és Mórágyi Gránit. Az IR-teszttel kimu- tatható szennyeződéseket gyakran földpát vagy csillám okozza. A Velencei Gránit és a Mórágyi Gránit szennyezettségét a termoanalitikai és a röntgen-pordiffrakciós vizsgálat is megerősítette, az előbbiek főként agyagásvány, az utóbbiak elsősorban csillám, illetve szmektit szennyezésre utaltak. A Tokodi és Zagyvai Formációk szeparátumaiban az IR spektrometria, a Tolvajárki Leukofillit esetében a RTG és az IR spektrometria is szennyezô ásványfázisokat jelzett. Néhány további szeparátum sem teljesen tiszta, azonban ez nem okozott problémát a lumineszcens mérések során, és a kvarc kormeghatározásában sem okozna gondot, mert a bennük található szennyezôk nem bocsátanak ki lumineszcenciát a kvarc OSL mérési tartományában, és így jó IRteszt eredményeket adtak (Törökbálinti Homokkő gödi mintája, Balatonfelvidéki Homokkő, Hárshegyi Homokkő, Bükkábrányi Lignit, Csatkai Formáció szeparátumai). Mivel a kvarcszeparátumok előállításához a 2,67g/cm³-nél nagyobb sûrüségú nehézfolyadékkal elválasztott könnyúfrakciót használtuk, és azon HF-os étetést is végeztünk, ezért elvileg a 2,67 g/ $\mathrm{cm}^{3}$ sûrüségú,és a kémiailag kevéssé ellenálló ásványok nem maradhattak a kvarcszemcsék mellett. A polarizációs mikroszkópos vizsgálat szerint azonban muszkovit, bontott földpát, kőzetüveg és kôzettöredék is előfordult egyes szeparátumokban, valamint a kvarcok különböző zárványokat (opak ásvány, cirkon, rutil, csillám, földpát, kianit) is tartalmaztak.

Annak, hogy a termoanalitikai mérések során az $\alpha$ kvarc- és $\beta$-kvarcmódosulatok közötti átmenet hőmérséklete az elméleti értéktől 0,2-0,5\%-kal eltért, több oka is lehet. Egyrészt az, hogy a mérési eredményeket a berendezés felépítése, valamint az adszorbeált gázok mennyisége és minősége is befolyásolja (SMYKATZ-KLOSS \& KLINKE 1997), másrészt olyan egyéb tényezők is, mint például a törés és előkészítés folyamata, a szemcseméret, a minta tömörítése, a tégely anyaga, a felfútés sebessége és a fütés során a mérési térben használt légkör minősége.

A kvarcba beépült idegen anyagok is különbségeket okoznak az OSL-ben (BAILEY 2001). A vizsgált képződmények kvarcszemcséiben a Si és O mellett Li, K, Al, Na, P, Ti és B fordult elő az LA-ICP-MS mérések eredményei szerint. Ezek a szennyezôk helyettesítés révén kristályrács hibapontokat hoznak létre, amelyek elsősorban infravörös spektroszkópia és paramágneses rezonancia (EPR) mérések segítségével mutathatók ki (pl. WEIL 1984, GöTZE et al. 2005, GuZZo et al. 2017). A Siं ${ }^{4+}$ helyén gyakran $\mathrm{Al}^{3+}, \mathrm{Ti}^{4+}$, esetleg $\mathrm{B}^{3+}$, vagy $\mathrm{Ge}^{4+}$ a helyettesítő (RHODEs 2011). Ilyenkor a töltéskompenzációt egy vegyértékú alkálifémion, pl. $\mathrm{Li}^{+}, \mathrm{Na}^{+}, \mathrm{K}^{+}$vagy hidrogénion $\left(\mathrm{H}^{+}\right.$, valójában $\left.\mathrm{OH}^{-}\right)$, illetve csapdázott lyuk biztosítja (MALIK et al. 1981, VARTANIAN et al. 2000). Az Al ${ }^{3+}$ és a Ti ${ }^{4+}$ az O-hiány helyét is elfoglalhatja (SAWAKUCHI et al. 2012).

Az OSL mérések során a közeli UV tartományban, 360-380 nm-nél jelentkezô lumineszcenciáért valószínúleg az Al-lyuk lumineszcens rekombinációs centrumok felelősek, de az alkálifémionok szerepe is fontos (HALLIBURTON et al. 1981, YANG \& MCKEEVER 1990). Erre utal, hogy ugyanolyan Al-tartalmú $\mathrm{H}^{+}$mentes szintetikus kvarc 
nagyobb intenzitású OSL-t adott nagyobb alkáli iontartalom esetén (RHODES 2011).

A kvarcban található szennyeződéseket egyrészt annak az olvadéknak vagy oldatnak az összetétele határozza meg, amelyből a kvarc kivált, másrészt a kvarc képződésének a hőmérséklete és a késôbbi felfútési események, mivel a magasabb hőmérséklet kedvez a szennyezók beépülésének és az olyan ponthibák kialakulásának, mint például az oxigénhiány. A hőmérséklet emelkedésével az egy vegyértékú töltéskompenzálók mobilisabbá válnak, és a kristályrácsban elvándorolva az elektroncsapdák és a fénykibocsátó rekombinációs centrumok számának változását okozzák, például egyes nem fénykibocsátó centrumok irreverzibilisen lumineszcens fénykibocsátóvá válnak, ami a lumineszcencia erôsödését okozza (VARTANIAN et al. 2000). HASHIMOTO et al. (1986) szerint a magas hőmérsékleten képződő magmás kőzetek kvarcában a nagyobb rácshiba, ill. lumineszcens centrum koncentráció gyors lehúlés során nem változik meg, pl. a vulkáni kvarcokban megôrződnek, de a plutóni kôzetek lassú megszilárdulása kihajtja a szennyező elemeket.

A szeparátumokon végzett LA-ICP-MS és mikro-FTIR mérési eredményeink csak tájékoztató jellegúek, mivel mintánként csak néhány kvarcszemcse került mérésre. A kvarcok általunk kimutatott idegenelem-koncentrációi és a kvarcszeparátumok OSL intenzitása közötti kapcsolatot vizsgálva (6. ábra) a $\mathrm{Li}, \mathrm{Na}, \mathrm{K}$ és $\mathrm{Ba}$ esetében negatív korreláció mutatkozott $(\mathrm{r}=-0,86 ;-0,75 ;-0,69 ;-0,53)$, a gyengébb OSL-t adó minták kvarcaiban ezek az elemek többnyire nagyobb koncentrációban voltak jelen, mint az erősebb lumineszcenciát adó szeparátumokban. A többi elem, köztük a fénykibocsátó lumineszcens centrumokat képezô Al esetében nem látszik szoros kapcsolat. Hasonló eredményre jutottak a korábbi kutatások is. MosKA \& MURRAY (2006) véleménye szerint a kvarc szennyezőinek koncentrációja direkt módon nem befolyásolja az OSL érzékenységet, mivel a nem érzékeny és érzékeny kvarcok kö- zött látszólag nincs nagy különbség ebben a tekintetben. Sharma et al. (2017) a kvarcok fémion- (Fe, Cr, Ni, Cu, La, $\mathrm{Ce}, \mathrm{Nd}, \mathrm{Tb}$ stb.) koncentrációját vizsgálták, és arra a következtetésre jutottak, hogy a fémszennyezők, köztük az Fe, amely lumineszcencia-gyengítő hatású, nem játszanak közvetlen szerepet az OSL érzékenység alakulásában, bár a szennyezők kumulatív hatását nem vizsgálták.

A kvarcszemcsékben mikro-FTIR mérésekkel azonosított $\mathrm{Si}^{4+}$ iont helyettesítô $\mathrm{Al}^{3+}+\mathrm{H}^{+}$, azaz $\mathrm{AlOH}$ szerkezeti hidroxil koncentrációk és az OSL intenzitások pozitív korrelációban vannak $(\mathrm{r}=0,55)$, a fóként (nano-)zárványokban található molekuláris víztartalom és az OSL között azonban nincs szoros kapcsolat (7. ábra).

A kvarcban a víz többféle módon lehet jelen. Egyrészt $\mathrm{H}_{2} \mathrm{O}$ molekula formájában a folyadék-gáz zárványokban és a kvarcszemcsék mikrorepedéseinek falán, másrészt szerkezetileg kötött formában, $\mathrm{a} \mathrm{SiO}_{4}^{4-}$ vázba beépülve, kémiailag kötve. Nagy hidroxiltartalmú kvarcokban $\mathrm{H}^{+}$, ill. $\mathrm{OH}^{-}$

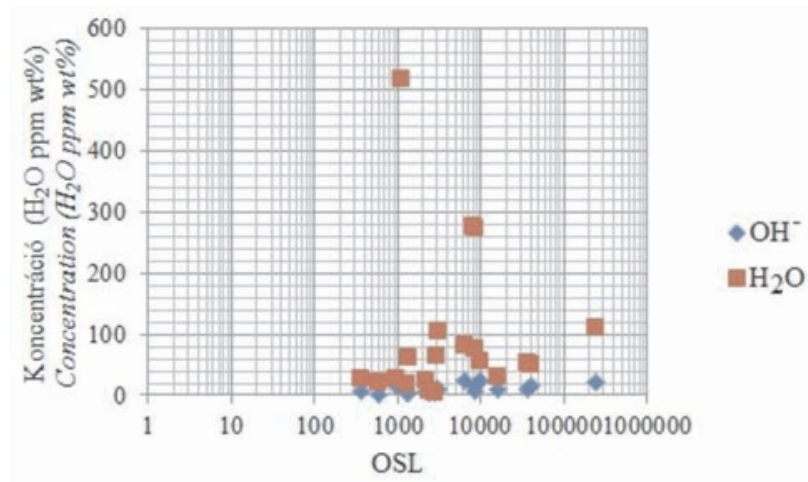

7. ábra. A vizsgált kvarcszeparátumok OSL intenzitásának és mikro-FTIR mérésekkel meghatározott $\mathrm{AlOH}$ szerkezeti hidroxil és molekuláris vízkoncentrációjának kapcsolata

Figure 7. OSL intensity of the studied quartz separates versus AlOH structural hydroxyl and molecular water content determined by Micro-FTIR measurements

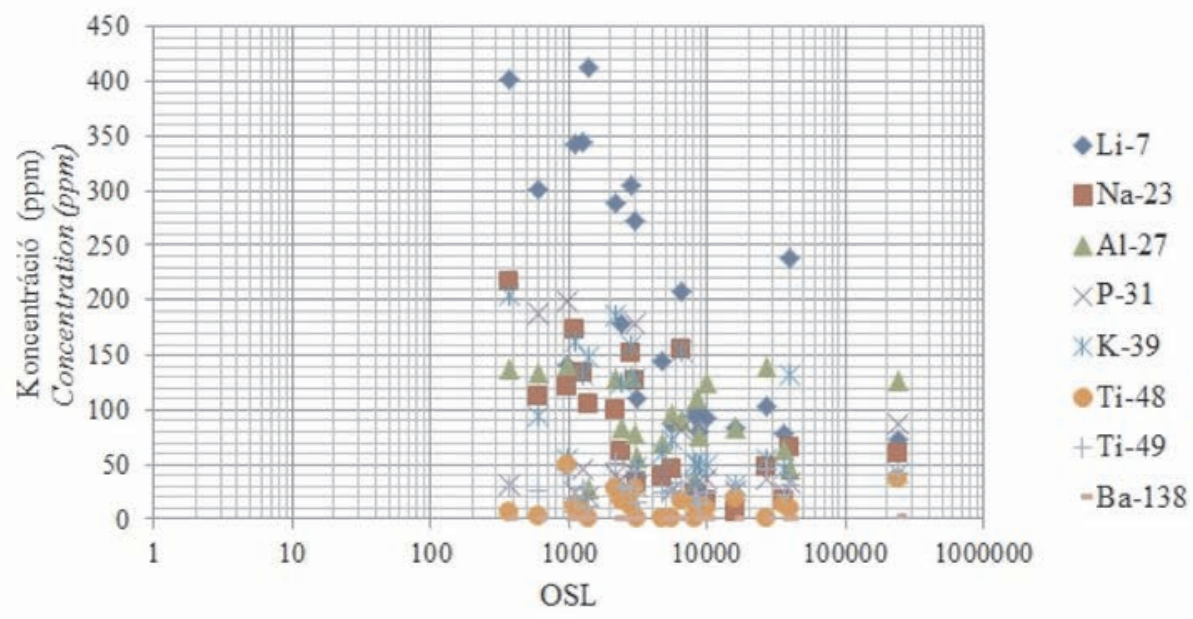

6. ábra. A vizsgált kvarcszeparátumok OSL intenzitásának és LA-ICP-MS mérésekkel meghatározott idegenelemtartalmának kapcsolata

Figure 6. OSL intensity of the studied quartz separates versus chemical element impurities determined by LA-ICP-MS measurements 
tartalmú lyukcsapdázó rekombinációs centrumok jellemzők (NutTal \& WeIL 1980, Weil 1984). A hidroxil és a víz, valamint az oxigénhiány rekombinációs centrumok az elektron és lyuk újraegyesülése során nem bocsátanak ki lumineszcens fényt, ellentétben pl. a fénykibocsátó $\mathrm{Al}$-lyuk centrumokkal (Rink 1994, SCHILLES et al. 2001, SHARMA et al. 2017). A rekombináció során tulajdonképpen verseny van a lumineszcens fénykibocsátó és a nem fénykibocsátó rekombinációs centrumok között (VARTANIAN et al. 2000, TAKASHI et al. 2006). A hidroxil, illetve a nyomelemekkel aqua-komplexeket képezó víz csökkenti az OSL érzékenységet, illetve a gyors OSL komponens részarányát, míg a kisebb víztartalmú kvarcok általában nagyobb OSL érzékenységúek (SHARMA et al. 2017).

Kvarcszeparátumaink esetében megfigyelhető, hogy a legtöbb magmás és metamorf kőzet kvarcában a szerkezeti hidroxil és molekuláris víz koncentrációja nagyon kicsi, a kimutatási határ alatti vagy ahhoz közeli volt. Ennek az lehet az oka, hogy ha a kvarcok hosszú idôt töltöttek magas hőmérsékleten, vagy metamorf viszonyok között, akkor több „lehetőséget", illetve idôt kaptak arra, hogy a szerkezeti hibáikat szilárd fázisú diffúzió útján kirelaxálják. Ugyanakkor a Tari Dácittufa mintáinak kvarcában már a kimutatási határ feletti hidroxil és molekuláris vízkoncentráció értékek jelentkeztek, amit a gyors kihúlés okozhatott, melynek során az $\mathrm{OH}^{-}$és $\mathrm{H}_{2} \mathrm{O}$ nem tudott eltávozni a kvarc kristályrácsából. Ide vonatkozó, az ignimbritek kvarcán végzett FTIR vizsgálati eredményeket közölt pl. BiRó et al. (2017) és Tollan et al. (2019).

A vizsgált kvarcokat befoglaló kôzetek és üledékek gamma-spektrometriai mérése alapján számított U-, Th- és K-koncentrációértékek és a képződményekből szeparált kvarcok OSL intenzitása között a K és Th esetében negatív korreláció mutatkozik ( 8 . ábra, $\mathrm{r}=-0,46 ;-0,37$ ), vagyis a nagyobb radioaktív elemkoncentrációjú képződmények kvarcai általában gyengébb OSL-t adtak. Ez a tendencia esetleg azzal függhet össze, hogy a kvarcban az ionizáló sugárzás hatására kristályrácshibák pl. többféle lyuk-centrum, illetve oxigénhiány centrum alakulhat ki (TRUKHIN et al. 2011), amelyek nem fénykibocsátó rekombinációs centrumokat képeznek.

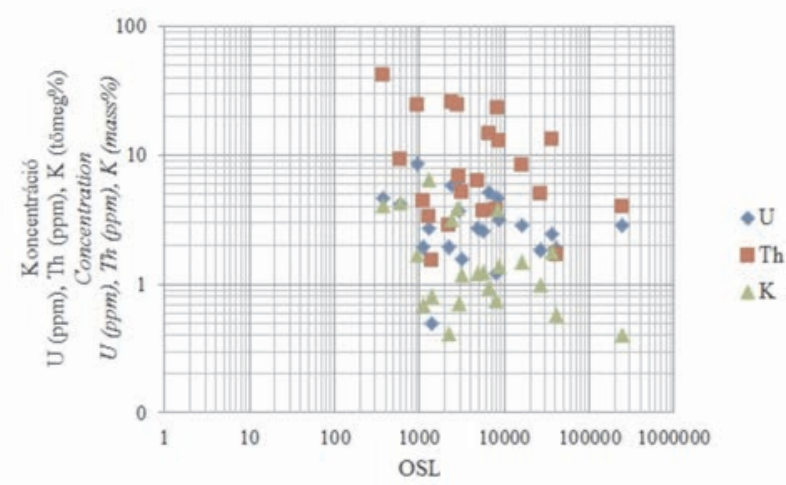

8. ábra. A vizsgált képződmények U-, Th- és K-koncentrációjának és a képződményekből szeparált kvarcok OSL intenzitásának kapcsolata

Figure 8. U, Th and K content of the studied formations versus the OSL intensity of their quartz separates
Két vulkáni és egy magmás kôzet kvarcszeparátumainak negyvenszer ismételt OSL lenullázása, radioaktív besugárzása és elómelegítése után végzett OSL mérési eredményeink csak nagyon kis mértékú érzékenységváltozást jeleznek.

A kvarc lumineszcens érzékenységét több tényező befolyásolja. A kristályosodása során beépült szennyeződések, illetve kialakult ponthibák mellett a későbbi felfútési események és a kvarc radioaktív besugárzástörténete is fontos tényezők. Az utóbbi magába foglalja a kvarc egész élettartama alatti idôt az eredeti befoglaló kőzetében, majd az üledékképződés során az üledékben és az áthalmozódások idején (Tsuкамото et al. 2011). A betemetődés alatti besugárzás, majd áthalmozódáskor napfényre kerülve az OSL lenullázódás ciklusainak száma is meghatározó (PIETSCH et al. 2008), mert a ciklusok alatt a nem lumineszcens centrumok aktiválódnak és fénykibocsátóvá válhatnak, illetve új lumineszcens centrumok is képződhetnek (SAWAKUCHI et al. 2012). Az üledékes ciklusok során történő OSL érzékenységnövekedés túlszárnyalja a kvarc magmás vagy metamorf képződési körülményeinek hatását (PIETSCH et al. 2008).

Az OSL mérések folyamán is változik a kvarc lumineszcens érzékenysége. Az alkalmazott radioaktív besugárzások a rácshibák közötti töltéscserét és/vagy új lumineszcens centrumok képződését eredményezhetik, ami kihat a töltések csapdázódási és rekombinációs folyamataira, például az $\mathrm{Al}^{3+}$ hiba lyukat csapdázhat, illetve hidrogén vagy alkáli ion által kompenzált Al-centrumok jöhetnek létre (VARTANIAN et al. 2000). Az OSL mérések során alkalmazott előmelegítés is változást okozhat a kvarc érzékenységében (MOSKA \& MuRRAY 2006). VARTANIAN et al. (2000) szerint az előmelegítés során a fénykibocsátó (Al-alkáli) rekombinációs centrumok számának növekedése eredményezi a kvarc OSL érzékenységének növekedését. Ezért az OSL kormeghatározás során olyan előmelegítési hőmérséklet alkalmazását javasolják, amely még nem érzékenyíti a kvarcot, bár a leggyakrabban alkalmazott SAR protokoll (MURRAY \& ROBERTS 1998) korrigálja az előmelegítés hatását. Az AlOH szerkezeti hidroxil hibák esetében azonban a kvarc OSL mérése során szokásos előmelegítéshez képest csak lényegesen magasabb hőmérséklet és hosszabb idejú hőhatás okozhat változást. A hőmérsékleti viszonyok és a kvarc által kibocsátott lumineszcencia összefüggése Mott-Seitz mechanizmusként ismert. Az ezen alapuló új modell szerint, amely leírja rekombinációs folyamatokat, csak $500^{\circ} \mathrm{C}$ felett mutatkoznak jelentősebb változások (PAGONIS et al. 2014).

Az ismételt laboratóriumi radioaktív besugárzási (OSL felépülési) és megvilágítási (OSL lenullázási) ciklusok — a természetben lejátszódó áthalmozáshoz, ismétlődő szállítási/lerakódási ciklusokhoz hasonlóan — melegítés nélkül is érzékenyebbé teszik a kvarc gyors OSL komponensét, ami azt is jelezheti, hogy a szennyezók koncentrációja direkt módon nem befolyásolja az érzékenységet (MOSKA \& MURRAY 2006). A megvilágítás, azaz fénnyel történő stimuláció során, ha az Al-centrumoknál rekombináció történik, akkor kétféle Al-hiba képződhet. Az egyik hidrogénionnal kompenzált hiba, amely nem ad lumineszcenciát az OSL mérési tartományban, a másik egy vegyértékủ alkáli ionnal 
kompenzált lumineszcens fénykibocsátó centrumhiba, amely az OSL intenzitás növekedését eredményezi különösen elómelegítés után (VARTANIAN et al. 2000).

SAWAKUCHI et al. $(2011,2012)$ magmás kózetek (gránitok, riolit, hidrotermális telér), metamorfitok (kékpala, csillámpalák, migmatit, gneiszek), valamint ismert eredetű folyóvízi és tengerparti üledékek kvarcainak lumineszcens tulajdonságait vizsgálva azt tapasztalták, hogy minden képződmény kvarcszemcséinek lumineszcens érzékenysége szignifikánsan variábilis volt, a fényes szemcsékben a gyors komponens dominált, és nagyobb érzékenységet mutattak azok a kőzetek, amelyek $500{ }^{\circ} \mathrm{C}$-nál nagyobb hômérsékleten alakultak ki (riolitok, amfibolit fáciesú és azt meghaladó metamorfitok). Megállapították, hogy a kvarc OSL érzékenységének alakulásában az egyik fố tényezô a kristályosodási hômérséklet, mivel magasabb hőmérsékleten több szennyező, pl. több Al és Ti épül be a kvarcba. A másik fontos tényezố az üledékes ciklusok száma, melyek során a betemetôdés és napfényre kerülés váltakozik. A két tényező közül az üledékes ciklusok hatása nagyobb, mint a kvarc forráskôzetétől örökölt érzékenysége, mivel a kvarc gyors OSL komponense egyre érzékenyebbé válik az üledékes ciklusok során.

Az üledékek esetében, ha a kvarcszemcsék nem adnak ki kezdeti fényes lumineszcenciát (pl. hiányzik a gyors komponensük), azt főként rövid üledékes történetük okozhatja, mintsem az, hogy milyen forráskőzetekből származnak (Тsuкамото et al. 2011), mivel az ismételt radioaktív besugárzás és megvilágítás hatására növekszik a kvarc OSL-jének érzékenysége (MOSKA \& MURRAY 2006, Preusser et al. 2006). Az általunk vizsgált képződmények közül például a tengerparti hullámverési övben képződött Kállai Kavics homokjában a hullámzás folyamatosan átmozgatta, áthalmozta a szemcséket, ami javíthatta a kvarcok lumineszcens tulajdonságait, növelhette az OSL intenzitásukat, érzékenységüket, és az OSL kormeghatározásra alkalmasabbá tehette őket. Ez a folyamat a szintén tengerparton lerakódott Törökbálinti Homokkő kvarcszemcséinek esetében is meghatározó lehetett.

Sok magmás és metamorf kőzet kvarcának az OSL szignáljából hiányzik a gyors komponens (pl. TsuкAмOTO et al. 2011), míg az üledékek kvarcában többnyire jelen van. Ennek oka, hogy az üledékes ciklusokon át növekszik a gyors és a közepes komponens részaránya (pl. FITzSIMMONS et al. 2010), és ezzel együtt a kvarc érzékenysége. Azt is kimutatták, hogy egy folyó mentén a szállítási távolsággal egyenes arányban növekszik a kvarc OSL érzékenysége, illetve lumineszcenciájának erőssége, amit az ismételt radioaktív besugárzás és napfényre kerülés okoz (PIETSCH et al. 2008).

MosKa \& MurRay (2006) szerint azt, hogy az ismételt radioaktív besugárzási és megvilágítási (kifakulási) ciklusok során növekszik a gyors OSL komponens érzékenysége, inkább a lumineszcens rekombinációs-valószínúség növekedése, mintsem a csapdázódási valószínúség növekedése okozza.

\section{Következtetések}

Az elvégzett OSL-mérések eredményei szerint a vizsgált képződmények közül csak néhánynak a kvarcszemcséi lennének alkalmasak a kormeghatározásra, ha a pleisztocén vagy holocén üledékekbe kerülnek. Ezek a képződmények elsốsorban a felső-miocén (pannóniai) Kállai Kavics homokjai és a felsô-oligocén Törökbálinti Homokkő, másodsorban a felsőmiocén-pliocén korú Zagyvai Formáció homokja. A felsőoligocén Csatkai Formáció és az alsó-oligocén Hárshegyi Homokkő kvarcszemcséi is fényes OSL-t és jó dózisvisszamérési arányt adtak, azonban viszonylag kis radioaktív sugárdózis hatásra telítôdtek, ami hátrányos a kormeghatározás szempontjából. A többi képződmény kvarcfrakciója vagy gyenge OSL-t adott, vagy rossz volt a dózisvisszamérési aránya, illetve fény hatására nehezebben ürültek ki a csapdái, ami miatt nem alkalmas az OSL kormeghatározásra.

A vizsgált kvarcok kristályrácshibáit a tájékoztató jellegú LA-ICP-MS vizsgálat eredményei szerint részben $\mathrm{Li}, \mathrm{Na}, \mathrm{Al}$, $\mathrm{P}, \mathrm{K}, \mathrm{Ti}$ és Ba beépülése okozhatja, illetve a mikro-FTIR mérésekkel kimutatott, $\mathrm{Si}^{4+}$ iont helyettesító $\mathrm{Al}^{3+}+\mathrm{H}^{+}$(azaz AlOH szerkezeti hidroxil) és molekuláris víz. Ezeknek a szennyezőknek egy része azonban ásványfázisok, fóként agyagásvány, illetve szmektit és csillám formájában is jelen van a kvarcszeparátumokban a RTG, a termoanalitikai és az IR spektrometriai vizsgálatok szerint. A nagyobb intenzitású OSL-t adó kvarcszeparátumok kvarcszemcséiben nagyobb $\mathrm{OH}^{-}$, és kisebb Li-, Na-, K- és Ba-koncentrációk voltak jellemző́k a gyengébb OSL-t kibocsátó szeparátumokhoz képest.

A gamma-spektrometriai mérési eredményekből kiderült, hogy a nagyobb OSL intenzitású kvarcokat befoglaló képződmények kisebb K- és Th-tartalommal rendelkeznek, mint a gyengébb lumineszcenciát kibocsátó kvarcok kőzetei, illetve üledékei, ami esetleg az ionizáló sugárzás hatására létrejövő nem fénykibocsátó rekombinációs centrumokkal függhet össze.

Összességében a vizsgálati eredményeink alapján a felsô-pleisztocén és holocén üledékeket alkotó kvarcok lumineszcens tulajdonságaiban és OSL kormeghatározásra való alkalmasságában mutatkozó helyi eltérések oka feltételezhetően a kvarcok eltérő forráskôzetei, valamint különböző hő- és üledékes történetük lehet. A forráskőzetek tekintetében meghatározó, hogy a metamorf és mélységi magmás kőzetek kvarcszemcséinek a lumineszcens tulajdonságai kedvezôtlenek az OSL kormeghatározás szempontjából. Ennek oka az lehet, hogy bár magas hőmérsékleten képződve sok kristályrácshiba alakult ki bennük, de hibáik nagy részét a lassú kihúlés során szilárd fázisú diffúzió útján kirelaxálták. Az üledékek és üledékes kôzetek kvarcszemcséi viszont kedvező́bb OSL tulajdonságokkal rendelkeznek, mivel az üledékképződés, különösen a szakaszos szállitás, illetve az áthalmozódás során több radioaktív besugárzási (azaz OSL felépülési) és napfényre kerülve OSL lenullázódási cikluson eshettek át, amelyek növelik a lumineszcens érzékenységet. Ezek a kvarcszemcsék a fiatalabb üledékekbe kerülve alkalmasabbak a kormeghatározásra.

A továbbkutatás során az egyedi kvarcszemcsék lumi- 
neszcenciájának vizsgálata és szennyeződéseik, illetve rácshibáik meghatározása vezethet pontosabb eredményekhez.

\section{Köszönetnyilvánítás}

Köszönettel tartozunk a minták rendelkezésünkre bocsátásáért Dr. PÉTERDI Bálint és Dr. KERCSMÁr Zsolt kollégáinknak, valamint WATAH Veronikának, aki a Herman
Ottó Múzeum Földtörténeti és Természetrajzi Tárának munkatársa, a minták előkészítéséért, illetve a preparátumok elkészítéséért BÁTORI Miklósnénak, Dr. GATTER Istvánnak és SIMON Istvánnak, a mérési adatok közötti korreláció vizsgálata során nyújtott segítségéért pedig TнAмó Csabának. Köszönjük Dr. Novothny Ágnes, Dr. Gucsik Arnold és anonim lektorunk értékes megjegyzéseit, tanácsait. A munkát a Nemzeti Kutatási, Fejlesztési és Innovációs Alap OTKA K128122 pályázata támogatta.

\section{Irodalom — References}

ADAMEIC, G. 2000: Variations in luminescence properties of single quartz grains and their consequences for equivalent dose estimation. — Radiation Measurements 32, 427-432. https://doi.org/10.1016/s1350-4487(00)00043-3

AITKEN, M. J. 1998: An introduction to optical dating: the dating of Quaternary sediments by the use of photon-stimulated luminescence. — Oxford University Press, 280 p. https://doi.org/10.1177/095968369900900314

BAILEY, R. M. 2001: Towards a general kinetic model for optically and thermally stimulated luminescence of quartz. — Radiation Measurements 33, 17-45. https://doi.org/10.1016/s1350-4487(00)00100-1

Bence G., Budai T. \& Csillag G. 1999: Kállai Formáció. In: Budai T. (szerk.): A Balaton-felvidék földtana: Magyarázó a Balatonfelvidék földtani térképéhez, 1:50 000. — Magyar Állami Földtani Intézet, Budapest, 108-109.

Biró, T., Kovács, I., Király, E., Falus, Gy., Karátson, D., Bendő, Zs., Fancsik, T. \& Sándorné Kovács, J. 2016: Concentration of hydroxyl defects in quartz from various rhyolitic ignimbrite horizons: results from unpolarized micro-FTIR analyses on unoriented phenocryst fragments. - European Journal of Mineralogy 28, 313-327. https://doi.org/10.1127/ejm/2016/0028-2515

Biró, T., Kovács, I. J., Karátson, D., Stalder, R., Király, E., Falus, Gy., Fancsik, T. \& Sándorné, J. K. 2017: Evidence for postdepositional diffusional loss of hydrogen in quartz phenocryst fragments within ignimbrites. — American Mineralogist: Journal of Earth and Planetary Materials 102/6, 1187-1201. https://doi.org/10.2138/am-2017-5861

Bøtter-Jensen, L., McKeever, S. W. S. \& Wintle, A. G. 2003: Optically Stimulated Luminescence Dosimetry. — Elsevier, 374 p. https://doi.org/10.1016/B978-0-444-50684-9.X5077-6

Bratyik, T., Sipos, Gy. \& Magyar, G. 2019: Quartz luminescence sensitivity of fluvial and aeolian samples in the Pannonian Basin. Geochronometria, Conference Abstract Series 2, p. 48, 13th International Conference "Methods of absolute chronology", 5-7 ${ }^{\text {th }}$ June 2019, Tarnowskie Góry, Poland.

Cserkész-Nagy, Á., Thamó-Bozsó, E., Tóth, T. \& SzTANó, O. 2012: Reconstruction of a Pleistocene meandering river in East Hungary by VHR seismic images, and its climatic implications. — Geomorphology 153-154, 205-218. https://doi.org/10.1016/j.geomorph. 2012.02.025

Duller, G. A. T., Bøtter-Jensen, L. \& Murray, A. S. 2000: Optical dating of single sand-sized grains of quartz: sources of variability. - Radiation Measurements 32, 453-457. https://doi.org/10.1016/s1350-4487(00)00055-x

FÁbián, Sz. Á., Kovács, J., Varga, G., Sipos, Gy., Horváth, Z., Thamó-Bozsó, E. \& Tóth, G. 2014: Distribution of relict permafrost features in the Pannonian Basin, Hungary. — Boreas 43/3, 722-732. https://doi.org/10.1111/bor.12046

Fiebig, M., Preusser, F., Steffen, D., Thamó-Bozsó, E., Grabner, M., Lair, G. J. \& Gerzabek, M. H. 2009: Luminescence dating of historical fluvial deposits from the River Danube and Ebro. — Geoarchaeology 24, 224-241. https://doi.org/10.1002/gea.20264

Fitzsimmons, K. E., Rhodes, E. J. \& BArrows, T. T. 2010: OSL dating of southeast Australian quartz: A preliminary assessment of the luminescence characteristics and behaviour. — Quaternary Geochronology 5,91-95. https://doi.org/10.1016/j.quageo.2009.02.009

FÜlöP J. 1990: Magyarország Geológiája. Paleozoikum I. — Magyar Állami Földtani Intézet, Budapest, 325 p.

GIDAI L. 1972: A dorogi terület eocénje. — A Magyar Állami Földtani Intézet Évkönyve 55/1, 140 p.

Götze, J., Plötze, M. \& Trautmann, T. 2005: Structure and luminescence characteristics of quartz from pegmatites. - American Mineralogist 90/1, 13-21. https://doi.org/10.2138/am.2005.1582

Guzzo, P. L., De SouzA, L. B. F, Barros, V. S. M. \& Khoury, H. J. 2017: Spectroscopic account of the point defects related to the sensitization of TL peaks beyond $220{ }^{\circ} \mathrm{C}$ in natural quartz. - Journal of Luminescence 188, 118-128. https://doi.org/10.1016/ j.jlumin.2017.04.009

GyARMATI P. 1974: Magyarázó a Tokaji hegység földtani térképéhez. 25 000-es sorozat. Sárospatak. — Magyar Állami Földtani Intézet, Budapest, $69 \mathrm{p}$.

HaHN GY., HudÁk É. \& LoBOdA Z. 1998: Az Észak-magyarországi-középhegység ásványi nyersanyagai és bányászata. — Földrajzi Értesítö 47/3, 317-358.

Halliburton, L. E., Koumvakallis, M. E., Markes, M. E. \& Martin, J. J. 1981: Radiation effects in crystalline $\mathrm{SiO}_{2}$ : the role of aluminum. - Journal of Applied Physics 52, 3565-3574. https://doi.org/10.1063/1.329138

Hashimoto, T., HaYAshi, Y., KoYANAGi, A. \& YoKosaKa, K. 1986: Red and blue colouration of thermoluminescence from natural quartz sands. - Nuclear Tracks and Radiation Measurements 11, 229-235. https://doi.org/10.1016/1359-0189(86)90039-7

HÁmOR G. 1985: A Nógrád-Cserháti kutatási terület földtani viszonyai. — Geologica Hungarica series Geologica 22, 1-213. 
Jain, M., Murray, A. S. \& BøtTer-Jensen, L. 2003: Characterisation of blue-light stimulated luminescence components in different quartz samples: implications for dose measurement. — Radiation Measurements 37, 441-449. https://doi.org/10.1016/s13504487(03)00052-0

JANTSKY B. 1979: A mecseki gránitosodott kristályos alaphegység földtana (Géologie du socle cristallin granitisé de la montagne Mecsek). — A Magyar Állami Földtani Intézet Évkönyve 60, 385 p.

JASKó S. 1981: Üledékfelhalmozódás és köszénképzôdés a neogénben. — A Magyar Állami Földtani Intézet alkalmi kiadványa, 157 p.

JÁmbor Á., Moldvay L., RónAi A., Szentes F. \& WeIn Gy. 1966: Magyarország földtani térképe 1:200 000. — A Magyar Állami Földtani Intézet kiadványa, Budapest.

KASZANITZKY F. 1956: Az alsóoligocén (hárshegyi) homokkő ásvány-kőzettani vizsgálata. — Földtani Kutatás 86, $244-256$.

Kats, A., HaVen, Y. \& Stevels, J. M. 1962: Hydroxyl groups in a-quartz. — Physics and Chemistry of Glasses 3, 69-75.

KERCSMÁR Zs. 2018: Eocén. — In: BUDAI T. (szerk.): A Gerecse hegység földtana. Magyarázó a Gerecse hegység tájegységi földtani térképéhez (1:50 000). Geology of the Gerecse Mountains. Explanatory Book to the Geological Map of the Gerecse Mountains (1: 50 000). — Magyar Bányászati és Földtani Szolgálat, Budapest, 57-106.

KishÁZI P. \& IVANCSICS J. 1989: A Soproni Gneisz Formáció genetikai kőzettana. — Földtani Közlöny 119/2, $153-166$.

KLUG, H. P. \& ALEXANDER, L. E. 1954: X-ray diffraction procedures for polycrystalline and amorphous materials. — Wiley, New York, $716 \mathrm{p}$.

KocH S. \& SzTróKAY K. 1967: Ásványtan I. — Nemzeti Tankönyvkiadó, Budapest, 359 p.

KoRPÁs L. 1981: A Dunántúli-középhegység oligocén-alsó-miocén képződményei. — A Magyar Állami Földtani Intézet Évkönyve 64, $140 \mathrm{p}$.

Kovács, I., Hermann, J., O’Neill, H. St. C., Fitz Gerald, J., Sambridge, M. \& Horváth, G. 2008: Quantitative absorbance spectroscopy with unpolarized light, Part II: Experimental evaluation and development of a protocol for quantitative analysis of mineral IR spectra. — American Mineralogist 93, 765-778. https://doi.org/10.2138/am.2008.2656

KRIZSÁN P. 1963: Összefoglaló földtani jelentés és készletszámítás a Kisörspuszta-Salföldi homok és kvarckő kutatásáról. — Kézirat, Magyar Állami Földtani, Geofizikai és Bányászati Adattár, Budapest.

Majoros Gy. 1999: Balatonfelvidéki Homokkő Formáció. — In: BuDAI T. (szerk.) A Balaton-felvidékföldtana: Magyarázó a Balatonfelvidék földtani térképéhez, 1:50 000. — Magyar Állami Földtani Intézet, Budapest, 26-31.

Malik, D.M., KohnKe, E.E. \& Sibley, W.A. 1981: Low temperature thermally stimulated luminescence of high quality quartz. Journal of Applied Physics 52, 3600-3605. https://doi.org/10.1063/1.329092

Marquet, J.-C., Lorblanchet, M., Oberlin, C., Thamo-Bozso, E. \& Aubry, T. 2016: Nouvelle datation du «masque» de La Roche Cotard (Langeais, Indre-et-Loire, France). (New dating of the "mask" of La Roche-Cotard (Langeais, Indre-et-Loire, France). — PALEO Revue d'archéologie préhistorique 27, 253-263. https://journals.openedition.org/paleo/3144

Marquet, J.-C., Macaire, J.-J., Bayle, G., Peyrouse, J.-B., Guillaud, É., Aubry, T., Liard, M., Bréhéret, J.-G., Thomsen, K. J., Freiesleben, T. H., Thamoné-Bozso, E., Guérin, G. \& Murray, A. S. 2019: Le site préhistorique de la Roche-Cotard IV (Indre-etLoire, France) : une séquence du pléistocene moyen et supérieur, référence pour le val de Loire tourangeau. (The prehistoric site of la Roche-Cotard IV (Indre-et-Loire, France): a middle and upper Pleistocene sequence, reference for the Val-de-Loire in Touraine). Quaternaire 30/2, 185-209. https://doi.org/10.4000/quaternaire.11746

Moska, P. \& Murray, A. S. 2006: Stability of the quartz fast-component in insensitive samples. — Radiation Measurements 41, 878885. https://doi.org/10.1016/j.radmeas.2006.06.005

Murray, A. S. \& Roberts, R.G. 1998: Measurement of the equivalent dose in quartz using a regenerative-dose single-aliquot protocol. — Radiation Measurements 29, 503-515. https://doi.org/10.1016/s1350-4487(98)00044-4

MurRay A.S. \& WinTLE A. G. 2000: Luminescence dating of quartz using an improved single-aliquot regenerative-dose protocol. — Radiation Measurements 32, 57-73. https://doi.org/10.1016/s1350-4487(99)00253-x

NAGY B. 1967: A velencei-hegységi gránitos kőzetek ásvány-kőzettani, geokémiai vizsgálata. — Földtani Közlöny 97/4, 423-436.

NÁdor, A., Thamó-Bozsó, E., MAGYARI, Á. \& BABInszKI, E. 2007: Fluvial responses to tectonics and climate change during the Late Weichselian in the eastern part of the Pannonian Basin (Hungary). — Sedimentary Geology 202/1-2, 174-192. https://doi.org/ 10.1016/j.sedgeo.2007.03.001

Nuttal, R. D. \& WeIL, J. A. 1980: Two hydrogenic trapped-hole species in $\alpha$-quartz. — Solid State Communications 33, 99-102. https://doi.org/10.1016/0038-1098(80)90705-X

Oláh P., Fodor L., Tóth T., DeÁk A., Drijkoningen G. \& Horváth F. 2014: A Szentendrei-sziget környéki folyóvízi szeizmikus szelvényezések földtani eredményei. — Földtani Közlöny 144/4, 359-380.

Pagonis, V., Chithambo, M. L., Chen, R., Chruścińska, A., Fasoli, M., Li, S. H., Martini, M. \& Ramseyer, K. 2014: Thermal dependence of luminescence lifetimes and radioluminescence in quartz. — Journal of Luminescence 145, 38-48. https://doi.org/ 10.1016/j.jlumin.2013.07.022

Pettke, T., Oberli, F., Audetat, A., Guillong, M., Simon, A., Hanley, J. \& Klemm, L. M. 2012: Recent developments in element concentration and isotope ratio analysis of individual fluid inclusions by laser ablation single and multiple collector ICP-MS. Ore Geology Reviews 44, 10-38. https://doi.org/10.1016/j.oregeorev.2011.11.001

Pietsch, T. J., Olley, J. M. \& Nanson, G. C. 2008: Fluvial transport as a natural luminescence sensitiser of quartz. — Quaternary Geochronology 3, 365-376. https://doi.org/10.1016/j.quageo.2007.12.005

Preusser, F., Ramseyer, K. \& Schluchter, C. 2006: Characterisation of low OSL intensity quartz from the New Zealand Alps. Radiation Measurements 41, 871-877. https://doi.org/10.1016/j.radmeas.2006.04.019

Preusser, F., Chithambo, M. L., Götte, T., Martini, M., Ramseyer, K., Sendezera, E. J., Susino, G. J. \& Wintle, A. G. 2009: Quartz as a natural luminescence dosimeter. —_Earth Science Reviews 97, 184-214. https://doi.org/10.1016/j.earscirev.2009.09.006 
RHodes, E. J. 2007: Quartz single grain OSL sensitivity distributions: implications for multiple grain single aliquot dating. Geochronometria 26, 19-29. https://doi.org/10.2478/v10003-007-0002-5

RHoDES, E. J. 2011: Optically stimulated luminescence dating of sediments over the past 200,000 years. — Annual Review of Earth and Planetary Sciences 39, 461-488. https://doi.org/10.1146/annurev-earth-040610-133425

RINK, W. J. 1994: Billion year age dependence of luminescence in granitic quartz. - Radiation measurements 23, 419-422. https://doi.org/10.1016/1350-4487(94)90074-4

Rink, W. J., Rendell, H., Marseglia, E. A., Luff, B. J. \& Townsend, P. D. 1993: Thermoluminescence spectra of igneous quartz and hydrothermal vein quartz. - Physics and Chemistry of Minerals 20, 353-361. https://doi.org/10.1007/bf00215106

Sambridge, M., FitzGerald, J., Kovács, I., O’Neill, H. St. C. \& Hermann, J. 2008: Quantitative absorbance spectroscopy with unpolarized light: Part I. Physical and mathematical development. — American Mineralogist 93, 751-764. https://doi.org/ 10.2138/am.2008.2657

Sawakuchi, A. O., Blair, M. W., Dewitt, R., Faleiros, F. M., Hyppolito, T. \& Guedes, C. C. F. 2011: Thermal history versus sedimentary history: OSL sensitivity of quartz grains extracted from rocks and sediments. — Quaternary Geochronology 6, 261272. https://doi.org/10.1016/j.quageo.2010.11.002

Sawakuchi, A. O., Guedes, C. C. F., DeWitt, R., Giannini, P. C. F., Blair, M. W., Nascimento, D. R. \& Faleiros, F. M. 2012: Quartz OSL sensitivity as a proxy for storm activity on the southern Brazilian coast during the Late Holocene. - Quaternary Geochronology 13, 92-102. https://doi.org/10.1016/j.quageo.2012.07.002

Schilles, T., Poolton, N. R. J., Bulur, E., Bøtter-Jensen, L., Murray, A. S., Smith, G., Riedi, P. C. \& Wagner, G. A. 2001: A multispectroscopic study of luminescence sensitivity changes in natural quartz induced by high-temperature annealing. — Journal of Physics D: Applied Physics 34, 722-731. https://doi.org/10.1088/0022-3727/34/5/310

Sharma, A. K., Chawla, S., Sastry, M. D., Gaonkar, M., Mane, S., Balaram, V. \& SingVi, A. 2017: Understanding the reasons for variations in luminescence sensitivity of natural quartz using spectroscopic and chemical studies. — Proceedings of the Indian National Science Academy 83, 645-653. https://doi.org/10.16943/ptinsa/2017/49024

SingARAYER, J. S. \& BAILEY, R. M. 2003: Further investigations of the quartz optically stimulated luminescence components using linear modulation. - Radiation Measurements 37, 451-458. https://doi.org/10.1016/s1350-4487(03)00062-3

Singh, V., TAndon, S. K., Singh, V., Mukul, M. \& Thamó-Bozsó, E. 2008: Geometry and development of the Jhajara thrust: An example of neotectonic activity in the Pinjaur Dun, NW Himalaya. - Current Science 94/5, 623-628.

SmyKatZ-Kloss, W. \& Klinke, W. 1997: The high-low quartz inversion. — Journal of Thermal Analysis and Calorimetry 48, 19-38. https://doi.org/10.1007/bf01978963

Sztanó O., Magyar I., Szónoky M., Lantos M., Müller P., Lenkey L., Katona L. \& Csillag G. 2013: A Tihanyi Formáció a Balaton környékén: típusszelvény, képződési körülmények, rétegtani jellemzés. — Földtani Közlöny 143/1, 73-98.

TAkashi, Y., Tomoyuki, T. \& Tetsuo, H. 2006: Dependence of luminescence sensitivities of quartz on $\alpha-\beta$-phase inversion break temperatures. — Radiation Measurements 41, 841-846. https://doi.org/10.1016/j.radmeas.2006.05.008

T. Biró K., Regenye J., Puszta S. \& Thamóné Bozsó E. 2010: Előzetes jelentés a Nagytevel-Tevel-hegyi kovabánya ásatásának eredményeiről. - Archaeologiai Értesító 135/1, 5-25.

THAмó-Bozsó, E. \& Ó. KovÁcs, L. 2007: Evolution of Quaternary to modern fluvial network in the Mid-Hungarian Plain, indicated by heavy mineral distributions and statistical analysis of heavy mineral data. - In: MANGE, M. A. \& WriGHT, D. T. (eds): Heavy minerals in use. - Developments in sedimentology 58, 491-514. https://doi.org/10.1016/s0070-4571(07)58019-2

Thamó-Bozsó, E., Magyari, Á., NAgy, A., Unger, Z. \& Kercsmár, Zs. 2007a: OSL dates and heavy mineral analysis of upper quaternary sediments from the valleys of the Ér and Berettyó rivers. — Geochronometria 281, 17-23. https://doi.org/10.2478/ v10003-007-0026-x

Thamó-Bozsó, E., Murray, A. S., NÁdor, A., Magyari, Á. \& Babinszki, E. 2007b: Investigation of river network evolution using luminescence dating and heavy mineral analysis of Late-Quaternary fluvial sands from the Great Hungarian Plain. - Quaternary Geochronology 2/1-4, 168-173. https://doi.org/10.1016/j.quageo.2006.05.012

Thamó-Bozsó, E., Csillag, G., Fodor, L. I., Müller, P. M. \& NAGY, A. 2010a: OSL-dating the Quaternary landscape evolution in the Vértes Hills forelands (Hungary). — Quaternary Geochronology 5/2-3, 120-124. https://doi.org/10.1016/j.quageo.2009.02.020

Thamó-Bozsó, E., Magyari, Á., Musitz, B. \& NAGY, A. 2010b: OSL ages and origin of Late Quaternary sediments in the North Transdanubian Hills (Hungary): timing of neotectonic activity. — Quaternary International 222, 209-220. https://doi.org/10.1016/ j.quaint.2009.07.023

Thamó-Bozsó, E., Füri, J., BÁtori, M.-né, Vígh, Cs., Nagy, A., Törökné Sinka, M. \& Horváth, Zs. 2019: Results of luminescence dating of samples from Iran I. — Kézirat, Magyar Bányászati és Földtani Szolgálat, Geokémiai és Laboratóriumi Osztály Adattára, Budapest, $32 \mathrm{p}$.

ThAmónÉ Bozsó E. \& NAGY A. 2011: Késő-negyedidőszaki üledékek betemetődési korának meghatározása kvarcszemcsék lumineszcens (OSL) vizsgálatával. — Földtani Közlöny 141, 41-56.

Thamóné Bozsó E., Király E., Kovács I., Füri J., Nagy A. \& TöröKné Sinka M. 2017: A kvarc optikai lumineszcens (OSL) tulajdonságainak vizsgálata. Kutatási jelentés, Magyar Bányászati és Földtani Szolgálat, Budapest. — Kézirat, Magyar Állami Földtani, Geofizikai és Bányászati Adattár, Budapest, 47 p.

Thomas, S.-M., Koch-Müller, M., Reichart, P., Rhede, D., Thomas, R., Wirth, R. \& Matsyuk, S. 2009: IR calibrations for water determination in olivine, $\mathrm{r}-\mathrm{GeO}_{2}$, and $\mathrm{SiO}_{2}$ polymorphs. — Physics and Chemistry of Minerals 36, 489-509. https://doi.org/10.1007/ s00269-009-0295-1

Tokuyasu, K., TANaKa, K., Tsukamoto, S. \& MurRay, A. S. 2010: The characteristics of OSL signal from quartz grains extracted from modern sediments in Japan. — Geochronometria 37, 13-19. https://doi.org/10.2478/v10003-010-0020-6 
Tollan, P., Ellis, B., Troch, J. \& NeukampF, J. 2019: Assessing magmatic volatile equilibria through FTIR spectroscopy of unexposed melt inclusions and their host quartz: a new technique and application to the Mesa Falls Tuff, Yellowstone. - Contributions to Mineralogy and Petrology 174/3, 24, 19 p. https://doi.org/10.1007/s00410-019-1561-y

TöRÖK, K. 1998: Magmatic and high-pressure metamorphic development of ortogneisses in the Sopron area, Eastern Alps (W-Hungary). - Neues Jahrbuch für Mineralogie, Abhandlungen 173/1, 63-91.

Trukhin, A. N., Smits, K., Chikvaidze, G., Dyuzheva, T. I. \& LityaginA, L. M. 2011: Luminescence of silicon dioxide - silica glass, $\alpha$ quartz and stishovite. - Central European Journal of Physics 9, 1106-1113. https://doi.org/10.2478/s11534-011-0016-5

Tsukamoto, S., Nagashima, K., Murray, A. S. \& Tada, R. 2011: Variations in OSL components from quartz from Japan Sea sediments and the possibility of reconstructing provenance. — Quaternary International 234, 182-189. https://doi.org/10.1016/j.quaint. 2010.09.003

Vartanian, E., Guibert, P., Roque, C., Bechtel, F. \& Schvoerer, M. 2000: Changes in OSL properties of quartz by preheating: An interpretation. — Radiation Measurements 32, 647-652. https://doi.org/10.1016/s1350-4487(00)00109-8

Vayssière, A., Rué, M., RecQ, C., Gardère, P., Thamó-Bozsó, E., Castanet, C., VirmouX, C. \& Gautier, E. 2019: Lateglacial changes in river morphologies of northwestern Europe: An example of a smooth response to climate forcing (Cher River, France). Geomorphology 342, 20-36. https://doi.org/10.1016/j.geomorph.2019.05.019

VECSERNYÉS Gy. 1966: A fehérvárcsurgói felső pannon kvarchomokösszlet kialakulása és ősföldrajzi jelentősége. — Földtani Kutatás 9/3, 1-9.

WEIL, J. A. 1984: A review of electron spin spectroscopy and its application to the study of paramagnetic defects in crystalline quartz. Physics and Chemistry of Minerals 10, 149-165. https://doi.org/10.1007/bf00311472

WESTAWAY, K. E. 2009: The red, white and blue of quartz luminescence: A comparison of $\mathrm{D}_{\mathrm{e}}$ values derived for sediments from Australia and Indonesia using thermoluminescence and optically stimulated luminescence emissions. — Radiation Measurements 44, 462466. https://doi.org/10.1016/j.radmeas.2009.06.001

Wintle, A. \& Murray, A. S. 2006: A review of quartz optically stimulated luminescence characteristics and their relevance in singlealiquot regeneration dating protocols. — Radiation Measurements 41, 369-391. https://doi.org/10.1016/j.radmeas.2005.11.001

YAng, X. H. \& McKeEver, S. W. S. 1990: Point defects and the pre-dose effect in quartz. - Radiation Protection Dosimetry 33, $27-30$. https://doi.org/10.1093/rpd/33.1-4.27

Kézirat beérkezett: 2019. 07. 09. 
